\title{
OPEN Enigmatic tracks of solitary sauropods roaming an extensive lacustrine megatracksite in Iberia
}

\author{
Fidel Torcida Fernández-Baldor ${ }^{1 凶}$, I. Díaz-Martínez ${ }^{2,3}$, P. Huerta ${ }^{4}$, D. Montero Huerta ${ }^{1}$ \& \\ D. Castanera 5
}

Sauropod remains are abundant on the Iberian Peninsula across the Jurassic-Cretaceous transition. Where the osteological record shows a high diversity of this kind of dinosaur, the ichnological findings are mainly limited to sauropod tracks characterized by kidney-shaped manus (with or without pollex impressions) and pes impressions with three claw imprints oriented laterally. Here, we present a new sauropod ichnotaxon, Iniestapodus burgensis, found at several exposures within the Las Sereas megatracksite (Burgos, Spain). These are preserved within lacustrine limestone strata of the Rupelo Formation (Tithonian-Berriasian). Iniestapodus burgensis is characterized by: semicircular manus tracks with small pollex impressions; unusual tetradactyl pes tracks with evidence of four claws oriented anteriorly (I-II) and laterally (III-IV), of variable sizes (short claw I and IV impressions, claw II and III being the largest). The combination of features and comparison with the osteological record allows us to propose a non-titanosaurian titanosauriform as a possible trackmaker. All the Iniestapodus tracks are represented by at least two different size classes of small and medium-sized individuals, and their trackways show different multidirectional orientations. The paleoenvironmental and paleoecological data suggest that Iniestapodus trackmakers were solitary individuals, likely representing different age classes, that crossed and used the Las Sereas shallow lacustrine-palustrine areas as their preferred habitat.

The Late Jurassic (Kimmeridgian-Tithonian) and Jurassic-Cretaceous (Tithonian-Berriasian) intervals constitute time periods in which most Iberian Peninsula sauropod tracks have been described, with significant sites in the Lusitanian, Asturian, Cameros, and Maestrazgo basins. Generally, these track impressions are characterized by a kidney-shaped manus (either with or without a claw impression on digit I) and subtriangular pes with claw impressions generally oriented anterolaterally, and have been associated with the Parabrontopoduslike/Breviparopus-like and Brontopodus-like ichnotypes ${ }^{1,2}$.

The sauropod osteological record, although from fewer sites, has yielded a large number of remains derived mainly from the Lusitanian basin ${ }^{3}$ and the Iberian Basin Rift System ${ }^{4,5}$. This record includes taxa ranging from basal Macronaria (Lourinhasaurus alenquerensis ${ }^{6}$ and Aragosaurus ischiaticus ${ }^{7}$ ), Titanosauriformes (Lusotitan atalaiensis $^{8}$, Galvesaurus herrero $i^{9}$ and Oceanotitan dantas $i^{10}$ ), Diplodocoidea (Dinheirosaurus lourinhanensis ${ }^{11}$ ) to Turiasauria (Losillasaurus giganteus ${ }^{12}$, Turiasaurus riodevensis ${ }^{4}$ and $Z$ Zy atlanticus ${ }^{13}$ ), as well as material not assigned to a specific taxon but representing the aforementioned four clades $3,5,14,15$.

In the Iberian context, the Tithonian-Berriasian Rupelo Formation (Tera Group, Cameros Basin) preserves, remarkably, both sauropod bones and tracks ${ }^{15-18}$. Recently, a humerus attributed to a basal brachiosaurid has been described ${ }^{15}$. In general, the sauropod tracks are preserved at the top of a carbonate level that is exposed over an extensive area with $\sim 14$ track-bearing outcrops along $5.6 \mathrm{~km}^{17}$. This extensive tracksite, which constitutes a megatracksite ${ }^{19}$, is called Las Sereas and preserves more than 1000 dinosaur footprints ${ }^{17}$. Theropod, ornithopod, thyreophoran, and sauropod tracks have been found, with the latter group being the most abundant ${ }^{17,18}$. Moreover, a singular sauropod dinosaur ichnotype, characterised by pes tracks with four claw impressions, was

\footnotetext{
${ }^{1}$ Museo de Dinosaurios de Salas de los Infantes and Colectivo Arqueológico y Paleontológico de Salas (CAS), Plaza Jesús Aparicio 9, 09600 Salas de los Infantes, Burgos, Spain. ${ }^{2}$ Universidad Nacional de Río Negro. Instituto de Investigación en Paleobiología y Geología, General Roca, Río Negro, Argentina. ${ }^{3}$ Instituto de Investigación en Paleobiología y Geología (IIPG), CONICET, Av. Roca 1242, 8332 General Roca, Río Negro, Argentina. ${ }^{4}$ Dpto. Geología, Escuela Politécnica Superior de Ávila, Universidad de Salamanca, Avda. Hornos Caleros, n 50, 05003 Ávila, Spain. ${ }^{5}$ nstitut Català de Paleontologia Miquel Crusafont, Universitat Autònoma de Barcelona, c/Escola Industrial 23, 08201 Sabadell, Barcelona, Spain. ${ }^{\varpi}$ email: fideltorcida@hotmail.com
} 


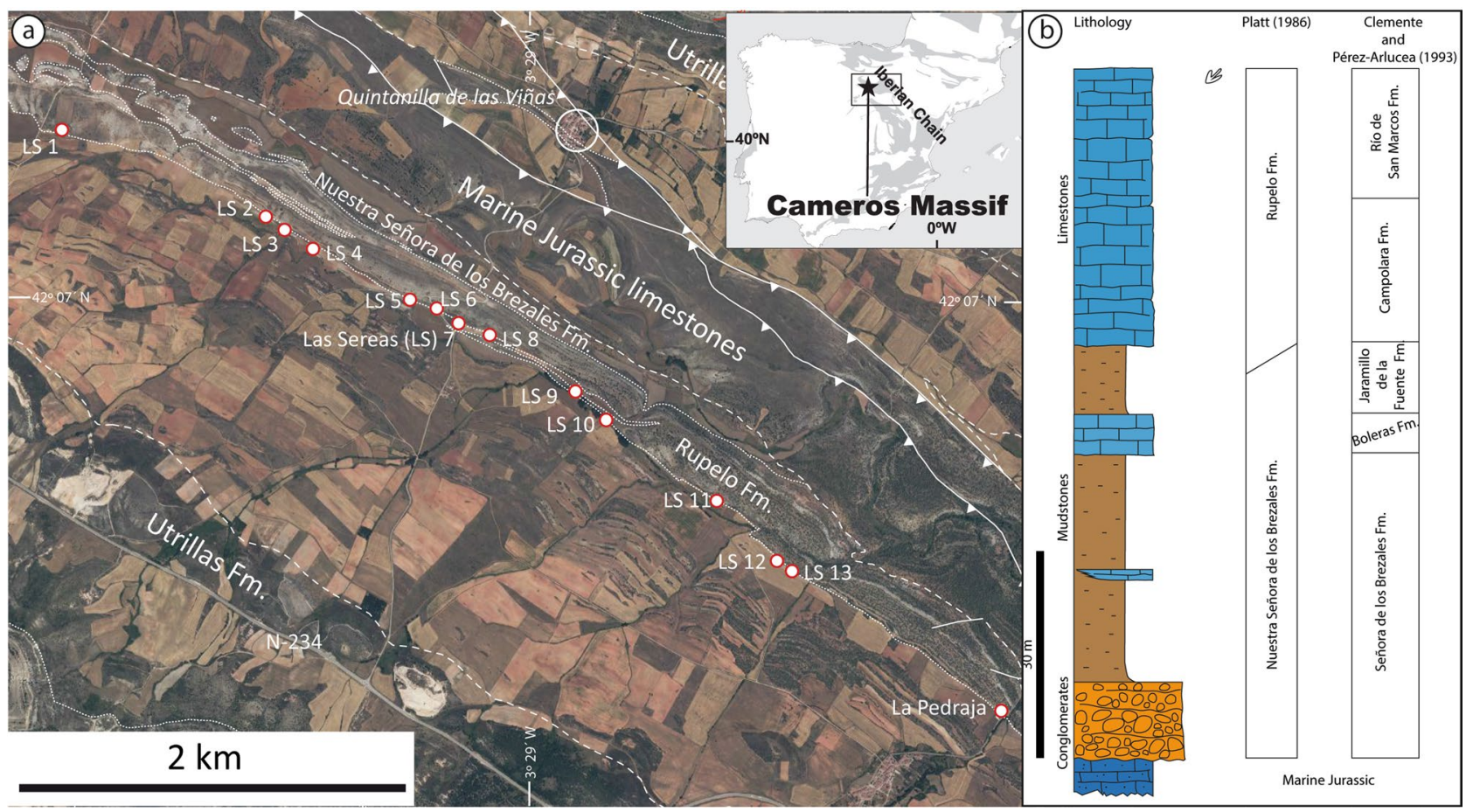

Figure 1. Geological and geographical setting of the Las Sereas tracksite. (a) Geological sketch showing the different tracksites at Las Sereas (LS 1-LS 13, and La Predraja). The map has been generated from fieldwork and mapped on the orthophoto (PNOA, www.ign.es) with Arcgis 10.3. (https://desktop.arcgis.com) (b) Schematic geological section from Quintanilla de las Viñas showing the equivalence of the units proposed by Platt $^{23}$ and those from Clemente and Perez-Arlucea ${ }^{25}$. The figure drawings were made with Adobe Illustrator CS2; the geological map, site locations, and the stratigraphic section were created by one of the authors (P. Huerta) of this manuscript.

described at one outcrop, Las Sereas 7 (LS7) ${ }^{18}$, within the Las Sereas megatracksite. Recently, new sauropod tracks and trackways with the same characteristics as this ichnotype, but of two different size classes, have been identified in two further Las Sereas outcrops. These recent discoveries expand the distribution and current information on these specific tracks and their trackmakers.

This study has multiple objectives. Firstly, the aims are to describe the new sauropod tracks, to compare them with tracks of the LS7 outcrop, and to analyze their ichnotaxonomic affinities. Secondly, herein we discuss the taxonomic relationships of the producers of these tracks. Finally, we infer the palaeoenvironmental and palaeoecological significance of the presence of these sauropod tracks in the lacustrine megatracksite of Las Sereas.

\section{Geological setting}

The Las Sereas tracksite is located $1.2 \mathrm{~km}$ SW of Quintanilla de las Viñas (SE of the Burgos province) and $10 \mathrm{~m}$ apart from the road BU-V-8207 (Fig. 1a). The sedimentary succession belongs to the western part of the Cameros Basin, which is located in the northwestern domain of the Iberian Basin Rift System that was developed during the Late Jurassic-Early Cretaceous ${ }^{20-22}$. The Las Sereas tracksite occurs at the top of the Rupelo Formation ${ }^{23,24}$. The upper part of the Rupelo Formation is equivalent, following other stratigraphic frameworks, to the Río

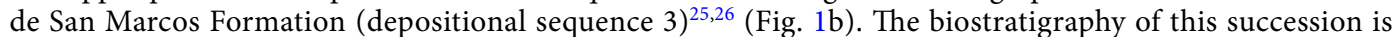
based on charophytes and ostracods and suggests a Tithonian-Berriasian age for the Rupelo Formation and equivalent lithostratigraphic units ${ }^{26,27}$. The upper part of the Rupelo Formation extends into the early to middle Berriasian ${ }^{22,24,28}$ based on the occurrence of Globator maillardii var. incrassatus in the Mambrillas section ${ }^{29}$ and on the Berriasian ostracod assemblage found in the underlying Campolara Formation ${ }^{27}$, which is equivalent to the middle part of the Rupelo Formation. These stratigraphic associations imply that the Las Sereas tracksite is Berriasian in age.

The Rupelo Formation comprises lacustrine and palustrine limestones with charophytes, ostracods, gastropods, dinosaur bones and tracks that have been interpreted as having been deposited on the low-gradient margin of a carbonate precipitating lake with seasonal lake level fluctuations and pedogenesis ${ }^{30}$. The occurrence of benthic foraminifers (miliolids) and dasycladales, in the upper part of the Rupelo Formation, is one of the key elements suggesting a new carbonate coastal wetland sedimentary model for the Río de San Marcos Formation ${ }^{22}$. The Las Sereas tracksite is located within the Quintanilla section, where little to no marine influence in the coastal wetlands is evident ${ }^{22}$. 
The Las Sereas tracksite occurs in one of the last limestone beds within the uppermost Rupelo Formation. This limestone bed has wackestone to packstone textures that, in some parts, show exposure features such as peloidal-intraclastic textures, alveolar and channel porosities, and vadose silt in vug or crack porosities. At the top of the bed, some circular impressions with diameters of $0.4-0.8 \mathrm{~cm}$ and lengths of $4-5 \mathrm{~cm}$ when are observed in section, are interpreted as marks of plant stems and/or roots.

\section{Material and methods}

In this work, the best-preserved quadrupedal tracks found in the Las Sereas 3 (LS3), Las Sereas 7 (LS7), and Las Sereas 8 (LS8) tracksites are documented and described. All the tracks are in situ and were documented using $2 \mathrm{D}$ cartography and photogrammetry of the most representative tracks in addition to a laser scanner model of part of the LS8 surface.

At the LS8 site, about 140 dinosaur tracks were identified, although the track-bearing level still needs additional fieldwork to be completely cleaned. However, trackway LS8A and two consecutive manus-pes sets have already been cleaned and were studied. The tracks were labelled according to previous conventions ${ }^{31,32}$, as follows: first, the tracksite identification (e.g., LS8); second, the trackway (e.g., A); third, separated by a comma, the footprint (e.g., ' 3 '); and fourth pes or manus abbreviations (e.g., p or m). For instance, LS8A, $2 \mathrm{~m}$ is the manus impression of the second manus-pes set of trackway A of tracksite LS8 (Las Sereas 8). LS8A is composed of 46 quadrupedal tracks (Table 1), whereas LS8B consists of two consecutive manus-pes sets: LS8B,1p/m and $\mathrm{LS} 8 \mathrm{~B}, 2 \mathrm{p} / \mathrm{m}$.

LS3 represents $\sim 400$ tracks on a heavily trampled surface ${ }^{33}$. Only three of the best-preserved tracks were selected for this study, one isolated pes track and one manus-pes set of tracks labeled as LS3,1 and LS3A,1p/m, respectively.

Tracks belonging to three trackways, LS7A, LS7B, and LS7C (Table 1), previously documented and classified as aff. Polyonyx $x^{18}$, are also included. Some tracks of the LS7C trackway have been redrawn and remeasured, according to new available data (photogrammetry), showing some differences with respect to the previous work ${ }^{18}$.

The LS7 and LS8 tracksites represent the same track-bearing surface and are separated by only $160 \mathrm{~m}$ distance (see Supplementary Fig. S1). The LS3 tracksite is more than $950 \mathrm{~m}$ away from LS7 and LS8, and the tracks are impressed in the same set of strata but on a different layer. The surfaces of the LS7 and LS8 tracksites were divided into $1 \times 1 \mathrm{~m}$ squares and each square was provided with a letter and a number to locate tracks with $\mathrm{x}$ - and y-coordinates. Field photos in LS3, LS7, and LS8 were taken with a Canon Power Shot S5IS camera (focal length $35 \mathrm{~mm}$, resolution $3264 \times 2448$ ). Photogrammetry was undertaken following the general methodology explained in Falkingham ${ }^{34}$, Mallison and Wings ${ }^{35}$, and Falkingham et al. $^{36}$. Generation of a three-dimensional, textured mesh was obtained running the process through the software Agisoft Metashape Pro (version 1.5.2, Educational License, http://www.agisoft.ru/) for a minimum of 10 to a maximum of 30 photos per track. Photogrammetric models in .obj format were also imported into CloudCompare (https://www.danielgm.net/cc/) to generate falsecolour depth maps. The LS8A trackway was digitally acquired via the terrestrial laser scanner Faro Focus 3D X330 from the CENIEH (Centro Nacional de Investigación sobre la Evolución Humana, Burgos, Spain), with a sampling resolution of $2 \mathrm{~mm}$, data collection speed of 976,000 points/s, and colour camera up to $70 \mathrm{mpx}$.

The terminology used in this paper mainly follows the works of Leonardi ${ }^{37}$, Farlow et al. ${ }^{38}$, and Thulborn ${ }^{39}$. The parameters were measured in the field and the laboratory and then verified using the 3D models. Several measurements were made (Supplementary Tables S1, S2): track length (L), track width (W), digit length (DLI, DLII, DLIII, DLIV), track rotation (FR), pace length (PL), stride length (SL), inner and outer trackway width (iTW-eTW), pace angulation (ANG), manus-pes distance (Dm-p), pes and manus width of the angulation pattern (WAP and WAM), and glenoacetabular distance (Gda) sensu Leonardi ${ }^{37}$. The heteropody was calculated with the heteropody index (HI) using the manus-pes area ratio $(\mathrm{H})$ of Lockley et al ${ }^{40}$ and the formula of González Riga and Calvo ${ }^{41}: \mathrm{HI}=[(\mathrm{Lm} \times \mathrm{Wm}) /(\mathrm{Lp} \times \mathrm{Wp})]^{\star} 100$. To quantify the trackway gauge, the pes and manus trackway ratio $\left(\mathrm{PTR}\right.$ and MTR) was calculated as $\mathrm{TR}=(\text { pesW/eTW })^{\star} 100^{42}$, and the WAP/PL ratio ${ }^{43}$ also was obtained. All parameters are given and compared in centimeters $(\mathrm{cm})$, except FR and ANG (in degrees), $\mathrm{H}$ (adimensional), HI and PTR, and MTR (in \%). Morphological quality (MP) has been analyzed using the scale proposed by Marchetti et al. ${ }^{44}$. Size classes follow Marty ${ }^{45}$, as: minute, $\mathrm{PL}<25 \mathrm{~cm}$; small, $25 \mathrm{~cm}<\mathrm{PL}<50 \mathrm{~cm}$; medium, $50 \mathrm{~cm}<\mathrm{PL}<75 \mathrm{~cm}$; and large, $\mathrm{PL}>75 \mathrm{~cm}$. The ichnotaxonomic analysis is based on the recommendations and ichnotaxobases proposed by Lockley et al..$^{40}$, Wright ${ }^{46}$, Castanera et al. ${ }^{2,47}$, Kim and Lockley ${ }^{48}$, Díaz-Martínez et al. ${ }^{49}$, and Marchetti et al. ${ }^{44}$. The possible trackmaker is discussed based on comparisons between the osteological descriptions of the main groups of sauropods, and other quadrupedal dinosaurs, and the ichnological features of the Las Sereas tracks. Moreover, the geographical and temporal correlations of both records are also discussed ${ }^{50}$.

Nomenclatural acts. The electronic edition of this article conforms to the requirements of the amended International Code of Zoological Nomenclature, and hence the new names contained herein are available under that Code from the electronic edition of this article. This published work and the nomenclatural acts it contains have been registered in ZooBank, the online registration system for the ICZN. The ZooBank LSIDs (Life Science Identifiers) can be resolved and the associated information viewed through any standard web browser by appending the LSID to the prefix "http://zoobank.org/". The LSID for the publication is: urn:lsid:zoobank. org:pub:AEBDF6D8-BEE9-498C-A895-CD1CFB3252BA. The electronic edition of this work was published in a journal with an ISSN, and has been archived and is available from the following digital repositories: PubMed Central, LOCKSS. 


\begin{tabular}{|l|l|}
\hline Trackway & Track labels \\
\hline LS7A & LS7A,1p/m; LS7A,2p/m; LS7A,3p/m; LS7A,4p/m; LS7A,5p/m; LS7A,6p/m; LS7A,7p/m; LS7A,8p/m; LS7A,9p/m; LS7A,10p/m \\
\hline LS7B & LS7B,1p/m; LS7B,2p/m; LS7B,3p/m; LS7B,4p/m; LS7B,5p; LS7B,6p; LS7B,7p \\
\hline LS7C & LS7C,1p/m; LS7C,2p/m, LS7C,3m and LS7C,4p/m \\
\hline LS8A & $\begin{array}{l}\text { LS8A,1p/m; LS8A,2p/m; LS8A,3p/m; LS8A,4p/m; LS8A,5p/m; LS8A,6p; LS8A,7p/m; LS8A,8p/m; LS8A,9p/m; LS8A,11p/m; } \\
\text { LS8A,12p/m; LS8A,13p/m; LS8A,14p/m; LS8A,15p/m; LS8A,16p; LS8A,19p/m; LS8A,20p/m; LS8A,21p/m; LS8A,22p/m; } \\
\text { LS8A,23p/m; LS8A,24p/m; LS8A,25p/m; LS8A,26p/m; LS8A,27p/m }\end{array}$ \\
\hline LS8B & LS8B,1p/m; LS8B,2p/m \\
\hline
\end{tabular}

Table 1. List of the tracks that belong to each studied trackway from the Las Sereas.

\section{Results and discussion}

Ichnotaxonomy. Iniestapodus ichnogenus nov.

urn:Isid:zoobank.org:act:1A792344-00DA-478E-B774-5C55D2902E6C

aff. Polyonyx Torcida Fernández-Baldor et al. (2015, Figs. 2, 3a-d, 4a-f, 5a,b) ${ }^{18}$

Type ichnospecies: Iniestapodus burgensis. Monospecific ichnogenus.

urn:lsid:zoobank.org:act:DDEF1EFE-9364-4C5C-BE94-D79910B303E3

Holotype: As for ichnospecies.

Paratypes: As for ichnospecies.

Type locality: As for ichnospecies.

Type horizon: As for ichnospecies.

Derivatio nominis: This ichnogenus is dedicated to Andrés Iniesta, the Spanish footballer who scored the winning goal in the 2010 World Cup final; -podus means foot in Greek.

Diagnosis: As for ichnospecies.

urn:lsid:zoobank.org:act:DDEF1EFE-9364-4C5C-BE94-D79910B303E3

Iniestapodus burgensis ichnosp. nov.

Holotype: A complete manus-pes set catalogued as LS7B,3m, and LS7B,3p. They are in situ and there is a photogrammetric model of both tracks.

Paratypes: The rest of the tracks of LS7B trackway, and the tracks included in LS7A, LS7C, LS8A, LS8B, LS3A,1p/m, and LS3,1 (see "Material and methods" for a complete list of tracks).

Type locality: Quintanilla de las Viñas (Burgos Province, Spain). Coordinates: UTM 30N (ETRS89) X 459,677; Y 4,662,743.

Type horizon: Rupelo Formation (upper part), Tithonian-Berriasian interval ${ }^{16}$, equivalent to Río San Marcos Formation, Berriasian in age $\mathrm{e}^{22,26,27}$.

Derivatio nominis: The ichnospecific epithet of "burgensis" means from Burgos, the Spanish province where the tracks were found.

Diagnosis: Manus tracks roughly symmetrical, wider than long, and have a semicircular shape. In the bestpreserved specimens, three short, broad, and rounded digit impressions (II, III, and IV) are anteriorly oriented, and a short and a subcircular digit I impression (pollex) is medially located. Pes tracks are longer than wide, with a subrectangular shape and four claw impressions. Claw I impression is smaller and more backwardly located than the others. Claw I and II impressions are forwardly oriented and impressions III and IV are slightly rotated and curved laterally. The lengths of the pes tracks are more than double that of manus tracks. The widths of the manus tracks are slightly smaller than the pes tracks. 

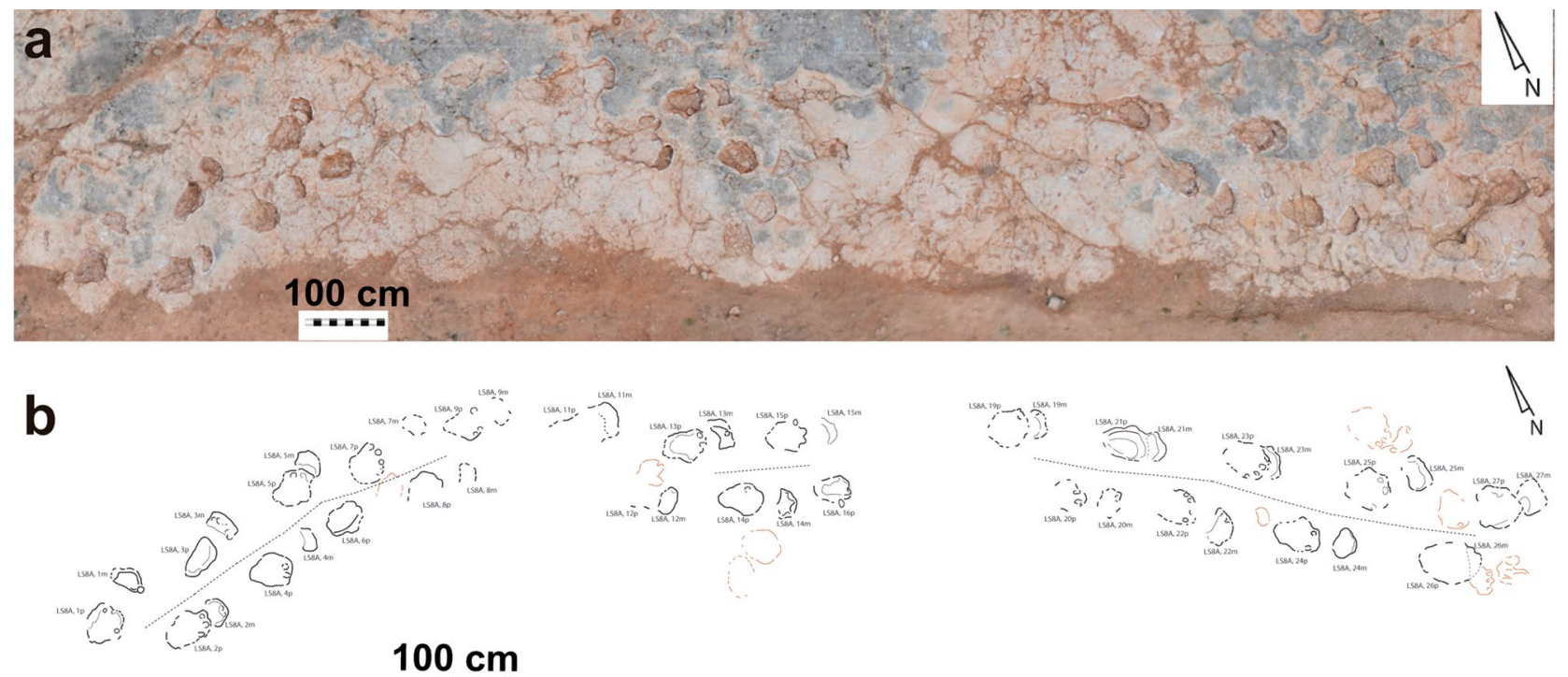

\section{$100 \mathrm{~cm}$}
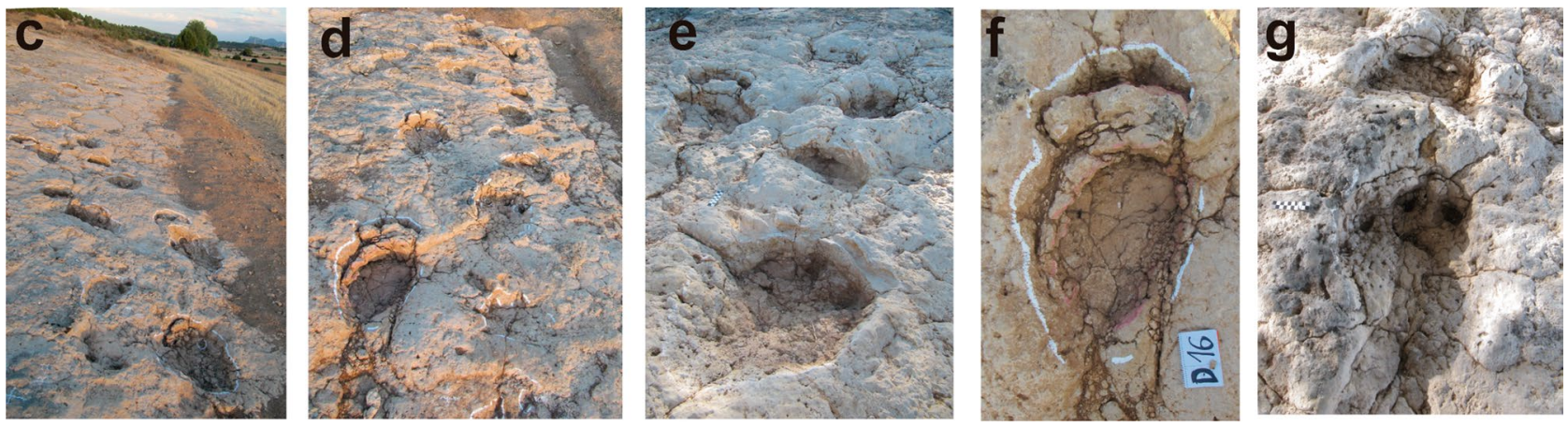

Figure 2. Las Sereas 8 tracksite. Tracks of Iniestapodus burgensis: (a) Ortophoto of LS8A trackway; (b) Interpretative cartography of LS8A trackway; (c) Initial section of LS8A trackway, from LS8A,1p to LS8A,7p; (d) Final section of LS8A trackway, from LS8A,20m to LS8A,27m; (e) A detail of the tracks LS8A,4p/ m; LS8A,5p/m; LS8A,6p; and LS8A,7p; (f) Pair LS8A,21p/m; (g) Pair LS8A,22p/m.

Description. Manus tracks indicate a morphology that varies from semicircular to crescent-shaped being wider than long (Figs. 2, 3, 4 and 5; Supplementary Table S1). Those of the LS7A and LS7B trackways are the largest ones (Supplementary Tables S2, Table S3). Averaged manus tracks measurements are: LS7A, $29 \mathrm{~cm}$ long and $40 \mathrm{~cm}$ wide, and LS7B, $28 \mathrm{~cm}$ long and $31 \mathrm{~cm}$. The manus tracks of LS7C and LS8A trackways and manus-pes set LS3A, 1p/m are slightly smaller and their mean values are $18 \mathrm{~cm}$ long and $28.5 \mathrm{~cm}$ wide in LS7C and $23 \mathrm{~cm}$ and $39 \mathrm{~cm}$ in LS8A (Supplementary Table S3). The manus track LS3A,1m is $18 \mathrm{~cm}$ long and $24 \mathrm{~cm}$ wide. Finally, the smallest manus tracks are those of LS8B, which measure an average of $11.7 \mathrm{~cm}$ long and $19.1 \mathrm{~cm}$ wide. The best-preserved manus impressions have three rounded digit impressions oriented anteriorly (digit II, III, and IV) and a small subcircular pollex impression oriented medially (e.g., LS7A, 8 m, 9 m, 10 m; LS8A,1m; Figs. 2b and $3 i-n)$. Several of them are deformed by overprinting of the pes tracks. The holotype manus track is semicircular, measures $29 \mathrm{~cm}$ long and $38 \mathrm{~cm}$ wide, and has a small and subcircular pollex impression (Supplementary Table S1; Fig. 3b-e). The morphological quality is variable from 0.5 to 2 (holotype has a value of 2).

Pes tracks are subrectangular in shape and the posterior edge is slightly protruding. They reveal four claw impressions occupying the entire width of the anterior zone, with the external claw impression (IV) located laterally and the internal (I) medially (Figs. 3, 4, 5). Claw I impression is in a more backward position than the others, and it is smaller than II, III, and IV that are similar in size (IV a bit smaller than II and III) (Fig. 3a,e). Claw I and II impressions are anteriorly directed, while III and IV are anterolaterally oriented. There are no impressions of a blunt callosity or a claw impression at the distal-lateral end of digit IV that might suggest the presence of a digit $\mathrm{V}$ impression. The pes tracks are longer than wide (Supplementary Table S3), and those of LS7A and LS7B are slightly larger than LS7C, LS8A, LS3A,1p, and LS3,1 but within the medium-sized class category. The means pes track measurements are: LS7A, $60 \mathrm{~cm}$ long and $43 \mathrm{~cm}$ wide; LS7B, $63 \mathrm{~cm}$ long and $43 \mathrm{~cm}$ wide; LS7C, $55.7 \mathrm{~cm}$ long and $33.7 \mathrm{~cm}$ wide; LS8A, $54 \mathrm{~cm}$ long and $41 \mathrm{~cm}$ wide. LS3A,1p/m presents a length-width of $57-34 \mathrm{~cm}$ and LS3,1 of 51-39 cm. The smallest pes tracks are those of LS8B (small size class), which measure a mean of $27 \mathrm{~cm}$ long and $23 \mathrm{~cm}$ wide. LS7 pes tracks are those with the highest morphological quality (some, including the holotype, with $>2$ on the morphological quality preservation scale). Pes tracks are generally deeper than the manus 
a

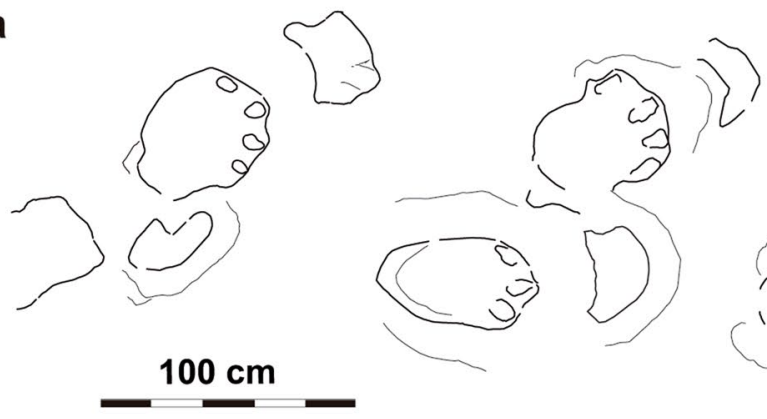

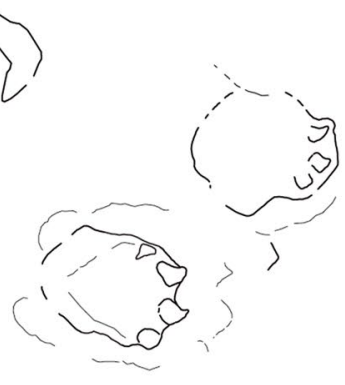
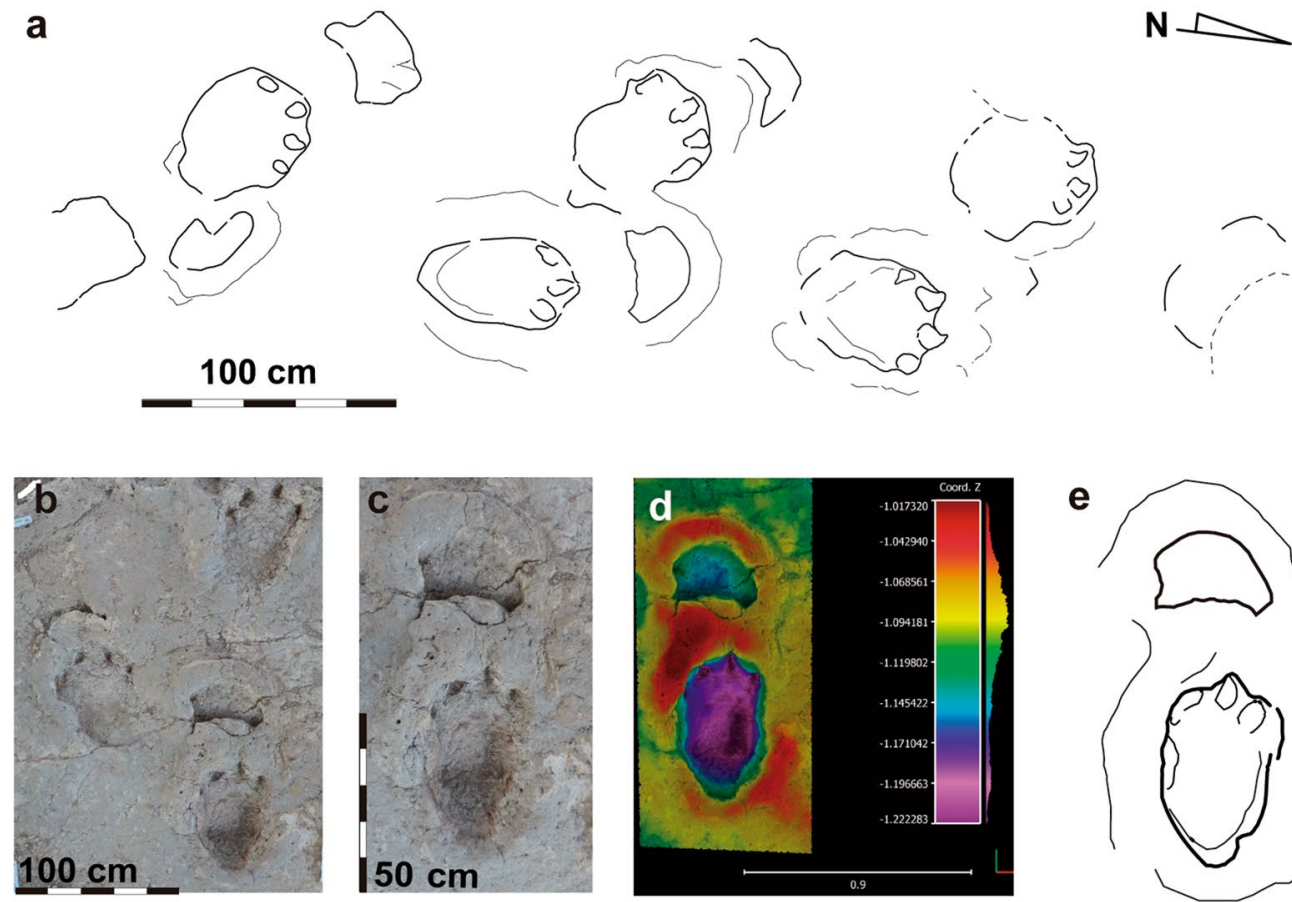

e
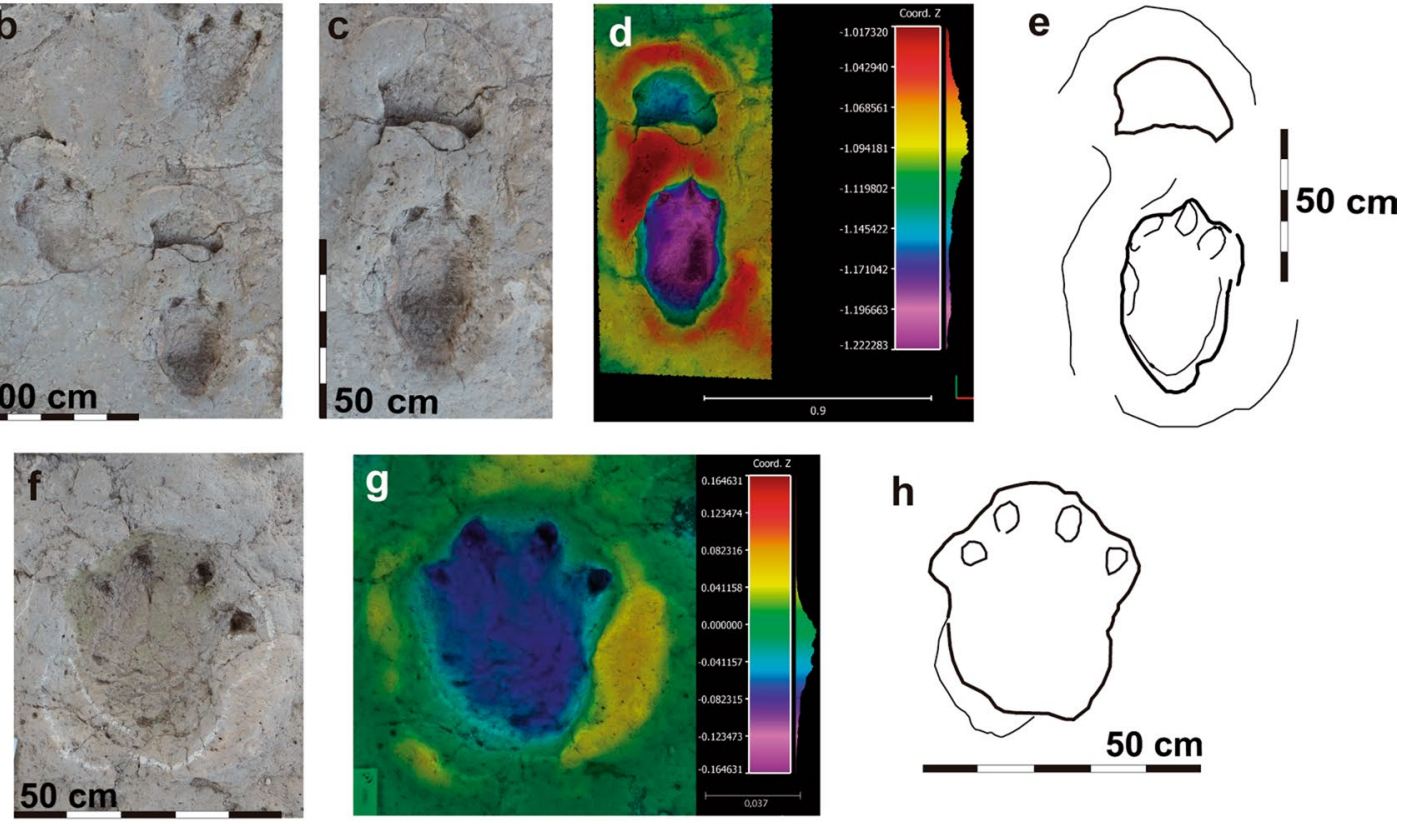

h
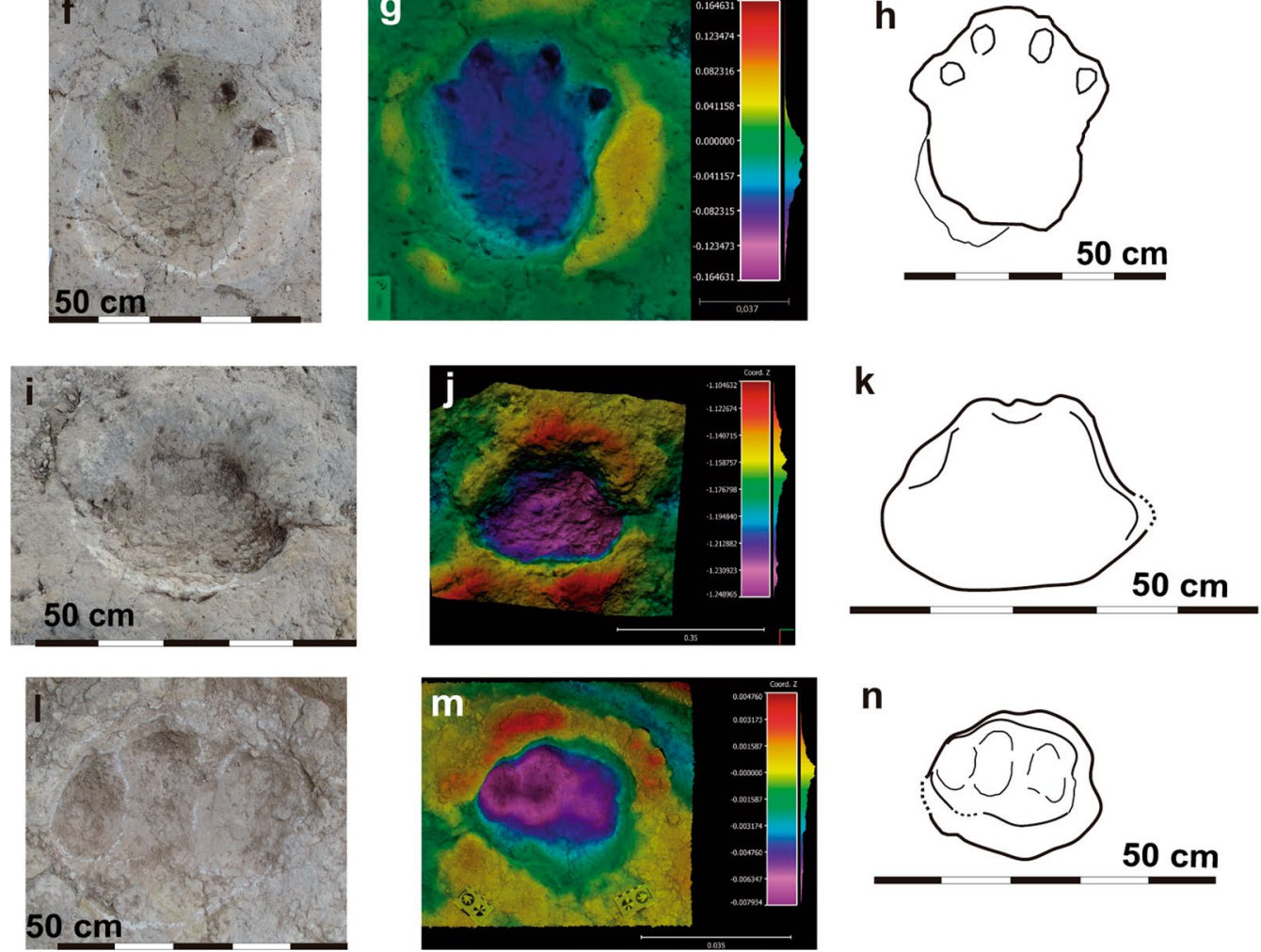

Figure 3. Las Sereas 7 tracksite. Holotype of Iniestapodus burgensis: (a) Interpretative cartography of LS7B trackway, modified from Torcida Fernández-Baldor et al. ${ }^{15}$. (b) Detail of the manus-pes sets LS7B,3p/m, $4 \mathrm{p} / \mathrm{m}$, and 5p. (c-e) Holotype LS7B,3p/m. (c) orthophoto; (d) false-color-depth map; (e) interpretative sketch. (f-h) Track LS7A,7p, right pes: (f) orthophoto; (g) false-color depth map; (h) interpretative sketch. (i-k) LS7A,8 m, left manus: (i) photography; (j) false-color depth map; (k) interpretative sketch. (i-n) LS7A,10m, right manus: (l) photography; (m) false*-color depth map; (n) interpretative sketch. The false-color depth map were generated with CloudCompare, a free software (http://www.cloudcompare.org/). 

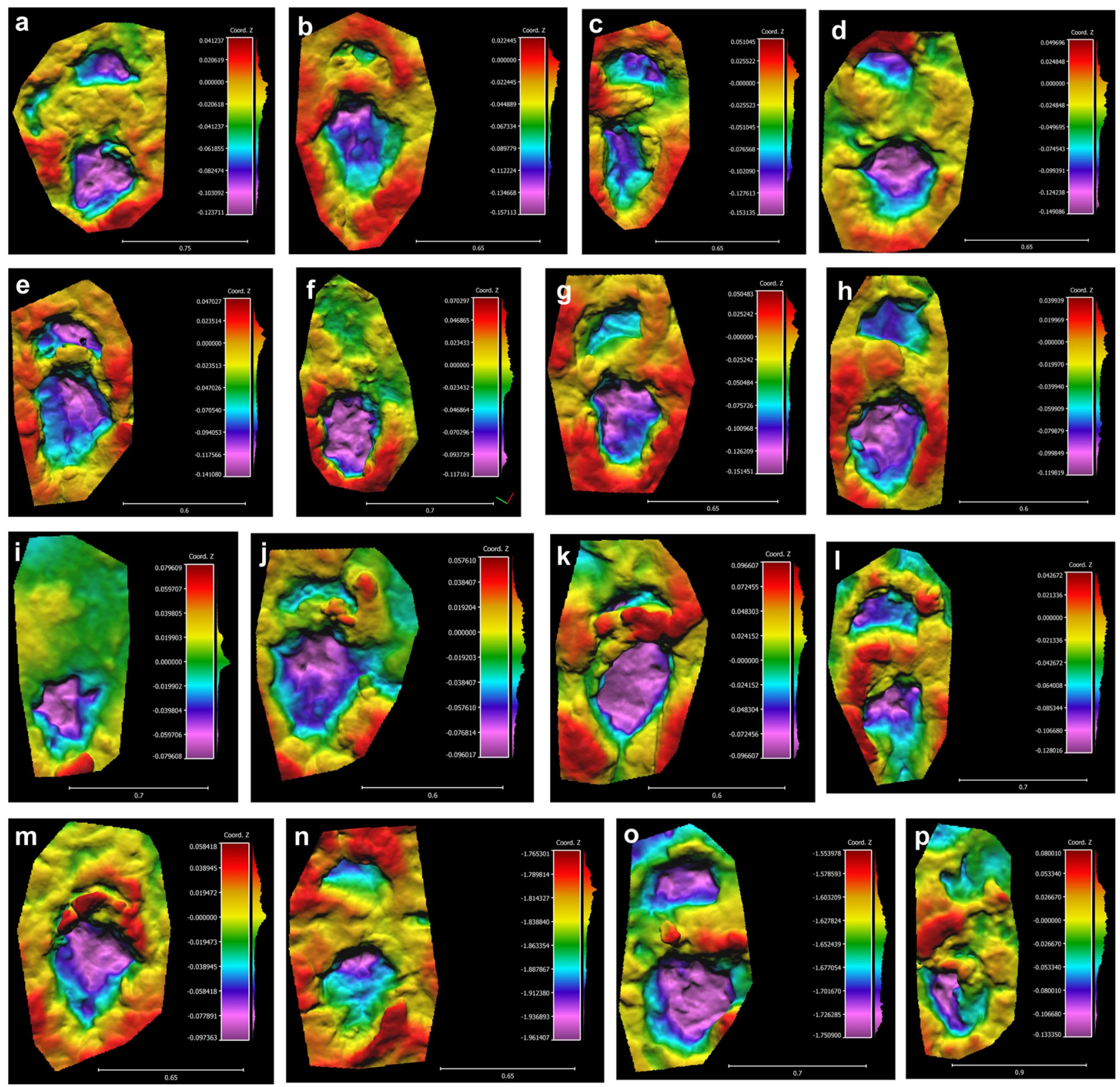

Figure 4. Las Sereas 8 tracksite. Tracks of Iniestapodus burgensis. False-color depth maps: (a) Pair LS8A,1p/m; (b) Pair LS8A,2p/m; (c) Pair LS8A,3p/m; (d) Pair LS8A,4p/m; (e) Pair LS8A,5p/m; (f) Pair LS8A,6p/m; (g) Pair LS8A,13p/m; (h) Pair LS8A,14p/m; (i) LS8A,16p; (j) Pair LS8A,19p/m; (k) Pair LS8A,21p/m; (l) Pair LS8A,22p/m; (m) Pair LS8A,23p/m; (n) Pair LS8A,24p/m; (o) Pair LS8A,25p/m; (p) Pair LS8A,26p/m. The false-color depth maps were generated with CloudCompare, a free software (http://www.cloudcompare.org/).

tracks (Figs. 3d, 4, 5b,e,k). The holotype pes track is subrectangular in shape and measures $65 \mathrm{~cm}$ long and $37 \mathrm{~cm}$ wide (Supplementary Table S1; Fig. 3b-e). Within the four claw impressions, the claw I is the smallest one and is medially located whereas claw III is the largest and is laterally rotated. The heteropody is variable from low to medium. For instance, LS8A reveals an heteropody of 1:2.7 and an heteropody index of 38.2\% (Supplementary Table S2) whereas LS7A and LS7B trackways have the same values: 1:2.5 and 41\% respectively.LS7C, LS8B, and LS3A have an heteropody of 1:3.7, 1:2.8, and 1:4.5, and a heteropody index of $47 \%, 37 \%$, and $22 \%$ respectively.

The trackways LS7A, LS7B, LS7C, and LS8A are sinuous along their lengths and are $\sim 7 \mathrm{~m}, 6 \mathrm{~m}, 4 \mathrm{~m}$, and $19 \mathrm{~m}$ long, respectively (see Torcida Fernández-Baldor et al. ${ }^{18}$ for a complete description of LS7 trackways; Fig. 1a,b). The distances between the pes tracks and the manus tracks vary (Fig. $2 \mathrm{f}, \mathrm{g}$ ), from more than $40 \mathrm{~cm}$ (e.g., LS8A, $1 \mathrm{p} / \mathrm{m}$ ) to a partial overlap (e.g., LA8A, $2 \mathrm{p} / \mathrm{m}$ ), probably due to the changes in trackway direction. LS7A comprises ten manus-pes couples. Trackways LS7B and LS7C are incomplete. The former has seven pes tracks and four manus tracks, while the latter presents three pes tracks and four manus tracks. LSA8 trackway preserves 24 pes tracks and 22 manus tracks (Fig. 2a,b). Some of the tracks are missing due to the broken surface or overlapping among some tracks (Fig. 2a,f). The LS7 tracks are generally deeper and have clear outlines (especially pes tracks), 

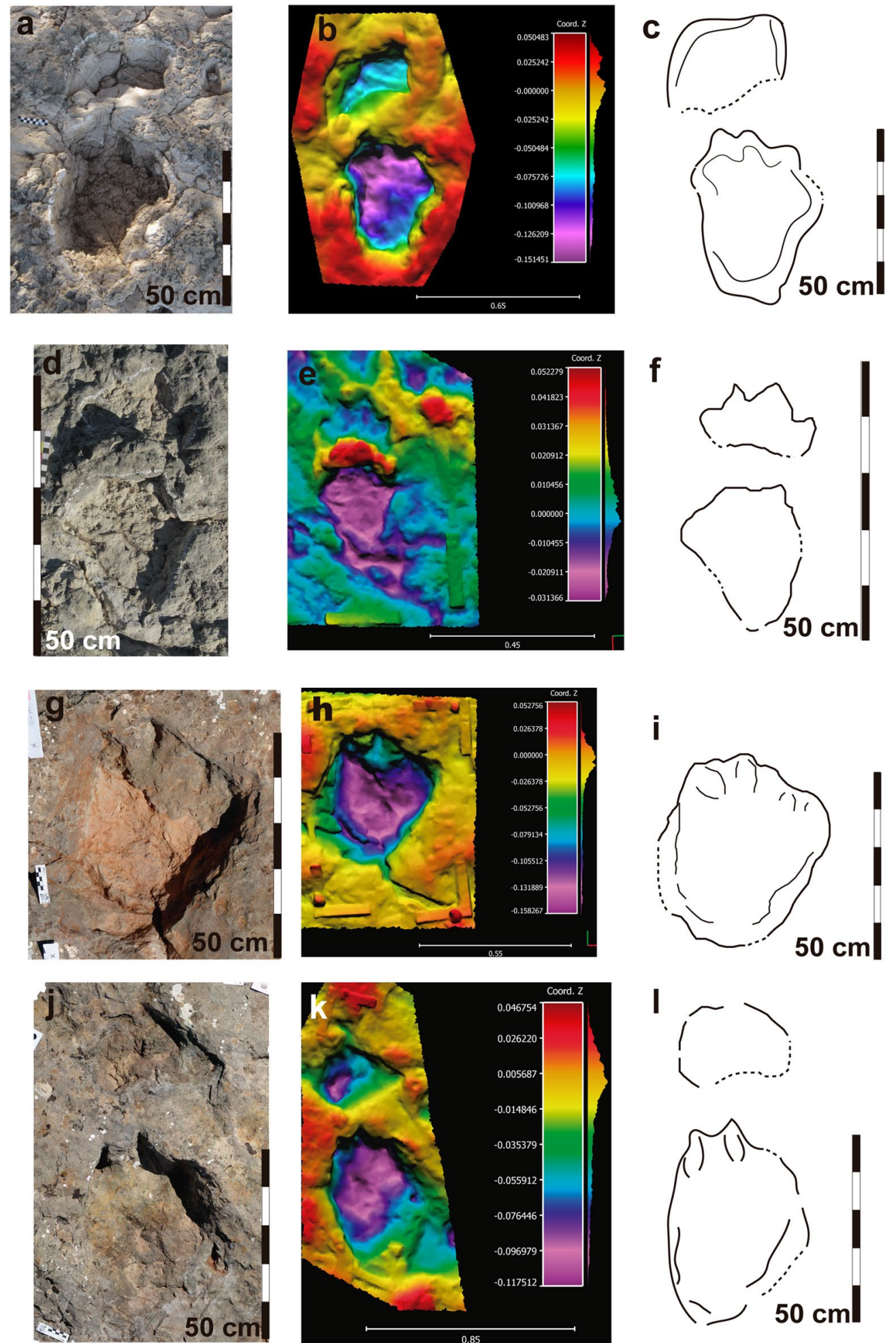

Figure 5. Other tracks of Iniestapodus burgensis. Pair LS8A,13p/m: (a), (b), (c). Pair LS8B,2p/m: (d), (e), (f). Pes track LS3,1: (g), (h), (i). Pair LS3A, 1p/m: (j), (k), (l). Left images: photographs (a); ortophotos (d), (g), (j). Central images: False-color depth maps (b), (e), (h), (k). Right images: Interpretative sketches (c), (f), (i), (l). The false color depth maps were generated with CloudCompare, a free software (http://www.cloudcompare.org/).

while those of LS8 are shallower. The trackway parameters are slightly different between LS7 and LS8 trackways (see Supplementary Table S2, and Torcida Fernández-Baldor et al. ${ }^{18}$ Tables 2 and 3). The pace length, of either the manus or pes, is variable among the trackways and within the same trackway. The same occurs with the stride length, track rotation, pace angulation, and the distance between manus and pes tracks (see Supplementary 


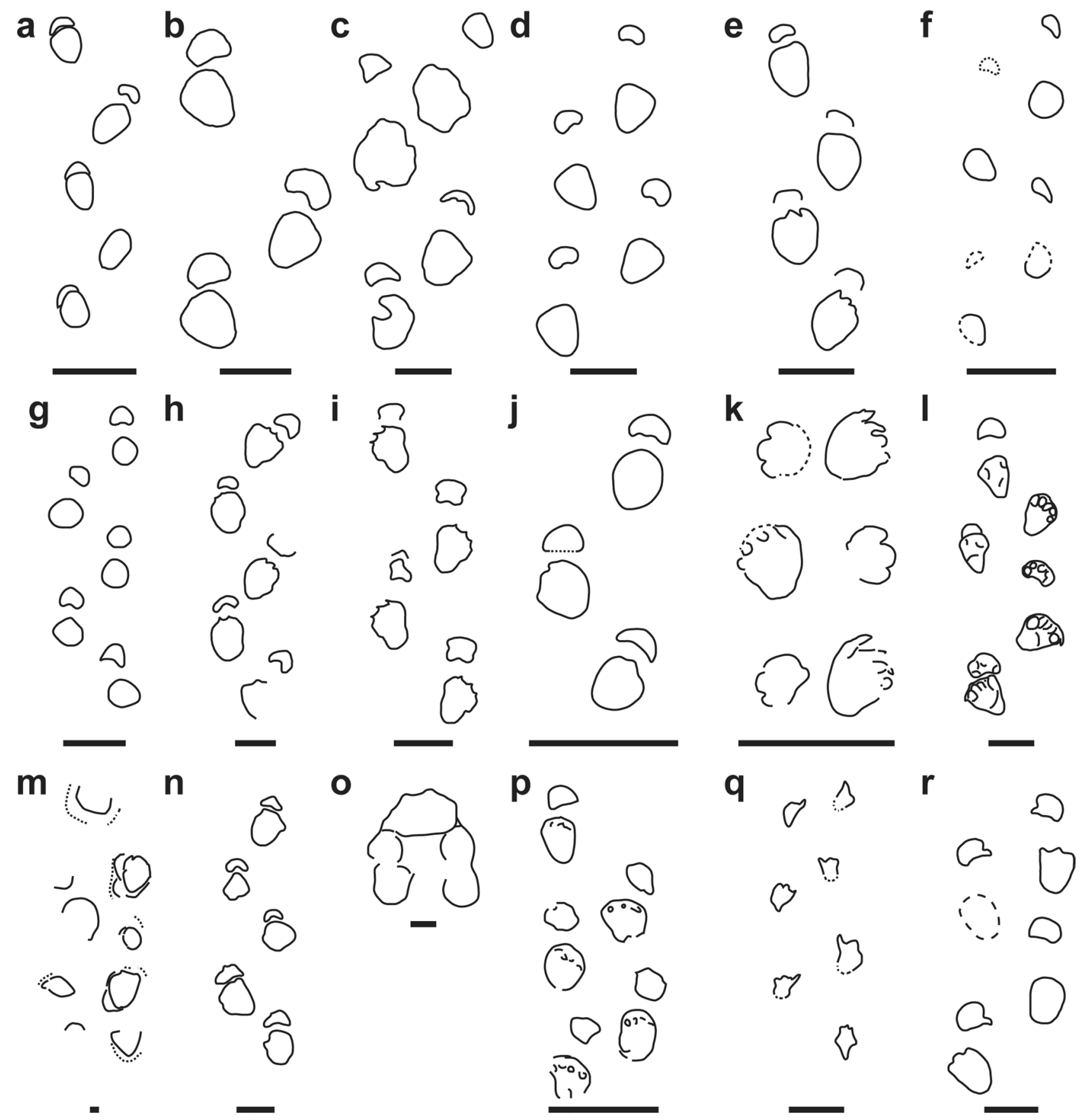

Figure 6. Main sauropod ichnotaxa described in the fossil record. (a) Elephantopoides Kaever and Lapparent, 1974 (redrawn from $^{64}$ ). (b) Rotundichnus Hendricks, 1981 (redrawn from ${ }^{69}$ ). (c) Gigantosauropus Mensink and Mertmann, 1984 (redrawn from ${ }^{70}$ ). (d) Sauropodichnus Calvo, 1991 (redrawn from ${ }^{67}$ ). (e) Parabrontopodus ${ }^{40}$. (f) Titanopodus $^{41}$. (g) Calorckosauripus [(redrawn from $\left.{ }^{68}\right]$ ). (h) Breviparopus Dutuit and Ouazzou, 1980 (redrawn from $^{71}$ ). (i) Brontopodus birdi $i^{38}$. (j) Brontopodus changlingensis Chen and Huang, 1993 (redrawn from ${ }^{72}$ ). $(\mathbf{k})$ Brontopodus pentadactylus $^{48}$. (1) Brontopodus plagnensis ${ }^{73}$. (m) Oobardjidama foulkesi ${ }^{74}$. (n) Occitanopodus gandi $i^{75}$. (o) Titanosaurimanus nana ${ }^{76}$. (p) Brontopodus oncalensis ${ }^{77}$. (q) Iguanodonichnus Casamiquela and Fasola, 1968 (redrawn from $\left.{ }^{78}\right)$. (r) Polyonyx gomesi ${ }^{79}$. Scale $1 \mathrm{~m}(5 \mathrm{~cm}$ in O).

Table S1 and Torcida Fernández-Baldor et al. ${ }^{18}$, Tables 2 and 3). The trackway gauge is intermediate: the PTR value $^{35}$ of LS7A is 43.9, and 47.6 in LS7B; in LS8A the PTR value is 35.3, which indicates an intermediate/widegauge trackway (Supplementary Tables S2, S3).

Remarks. The ichnotaxonomy of the tracks of obligate quadrupedal dinosaurs is a complex topic. The tracks of sauropodomorphs, thyreophorans, and ceratopsians are represented in this category ${ }^{19,39,40,51-53}$. Iniestapodus differs from ceratopsian and thyreophoran (ankylosaurian and stegosaurian) ichnotaxa in the number (four vs 
three to five), morphology (sharp vs blunt), and orientation (two-digit impressions oriented anteriorly and the other two laterally vs anteriorly) of pes claw impressions $s^{52-58}$. Regarding coeval ichnotaxa of other non-sauropod quadrupedal dinosaurs, the thyreophoran ichnogenus Deltapodus ${ }^{56}$ has a mesaxonic pes with three functional and anteriorly oriented digits; it differs from the tetradactyl pes of Iniestapodus with two anteriorly- and two -oriented digits. Deltapodus tracks (D. ibericus and $D$. isp) have been described in coeval deposits of the Iberian Range $^{57,58}$, and are different to Iniestapodus in manus and pes shape, the tridactyl condition of the pes and, especially, in the blunt claw impressions. Metatetrapous valdensis, a thyreophoran ichnotaxon from the Berriasian of Germany, also presents four digital impressions in the pes tracks. It differs from Iniestapodus in its tetradactyl manus, a narrower gauge, orientation of the claw impressions, and the heel morphology in the pes ${ }^{53,54}$. Moreover, it is different from some basal sauropodomorph ichnotaxa (e.g., Otozoum) typical of the Late Triassic and Early Jurassic, that are tetradactyl, with its well-developed and separated digit I-IV impressions and narrow and elongate heel impressions $\mathrm{s}^{59-64}$. Iniestapodus pes tracks typically always have four distinct claw impressions lacking elongate digit impressions, and its heel imprint is wider.

Iniestapodus differs (Fig. 6) from almost all sauropod ichnotaxa because it reveals tetradactyl pes tracks with evidence of four sharp claw impressions. For instance, many of them have less than four claw impressions, or no claw impressions preserved. These include: Elephantopoides; Rotundichnus; Gigantosauropus; Sauropodichnus; Parabrontopodus; Titanopodus; and Calorckosauripus ${ }^{40,41,64-68}$ (Fig. 6a-g).

Some sauropod ichnotaxa have pes tracks showing tetradactyl and pentadactyl digit impressions: Breviparopus; Brontopodus with the ichnospecies: B. birdi; B. changlingensis, B. pentadactylus; and B. plagnensis; Oobard-

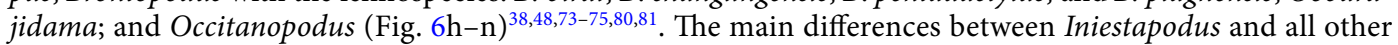
known sauropod pes tracks are its generally outwardly rotated claw impressions, with a notable decrease in their size from I to IV, with claw IV being very small, and usually blunt, or with no claw trace. Moreover, none of these ichnotaxa preserve a pollex impression in the manus, a key feature in Iniestapodus. The sauropod ichnotaxon Titanosaurimanus ${ }^{76}$ is known only from a manus track, which has a horseshoe shape, different from the semicircular morphology of the manus of Iniestapodus (Fig. 6o). The pes tracks of Brontopodus oncalensis ${ }^{77}$ were described as triangular, with four possible claw impressions and the manus tracks as subcircular to pentagonal (Fig. 6p). In a recent visit to the type locality of B. oncalensis (D.C. and F.T., May 2019), it was not possible to identify the presence of clear claw impressions in the holotype trackway. The track-bearing layer is very eroded, and the tracks are poorly preserved, not reaching a morphological quality higher than 1; thus, this ichnotaxon is herein considered as nomen dubium following Marchetti ${ }^{44}$.

On the other hand, the pes tracks of Iguanodonichnus ${ }^{82}$, considered as a sauropod ichnotaxon by Moreno and Benton ${ }^{78}$, has four claw impressions, with a prominent claw in digit I and directed forwardly; and claws on digits II, III, and IV are strongly reduced (Fig. 6q). In Iniestapodus, the claw I digit impression is the smallest of the pes track.

The ichnotaxon Polyony $x^{79}$, which had been compared to the Las Sereas sauropod tracks in previous work ${ }^{18}$, has a tetradactyl pes that is oval (Fig. 6r). The claw impressions are similar in length, with two claw impressions at an anterior orientation (digits I-II) and the other two (digits III-IV) laterally oriented. Manus tracks have five-digit impressions, with the digit I (pollex) the largest and oriented in a medial to posteromedial direction. Iniestapodus shares the orientation of the digit pes impressions with Polyonyx, but differs in its general shape (subrectangular vs. oval in shape), size, and the position of pes digit I impressions (smaller than digits II and III, and more backward than the other digit impressions vs. similar size and position than the other digit impressions). Both ichnotaxa are clearly different in manus morphology and especially in the size and orientation of pollex impression (small vs large, and medial-posteromedial vs posterior). Moreover, Iniestapodus differs from Polyonyx in the heteropody (intermediate to low in the former, and low in the latter) and in trackway gauge (intermediate Iniestapodus and wide in Polyonyx).

In conclusion, the differences between Iniestapodus and the other quadrupedal dinosaur ichnotaxa justify the erection of the new ichnotaxon.

Trackmaker. In general, an ideal trackmaker identification should reflect similar derived anatomical characteristics (phylogenetic correlation) and the main similarities between the track and the autopod skeleton (phenetic correlation), plus a geographic-temporal distribution (coincidence correlation) ${ }^{50}$. Regarding sauropod pedes and manus, several authors have pointed out an evolutionary process of phalanx reduction, both in the number and proportional size of the phalanges ${ }^{83-91}$. A progressive reduction of the phalanges of the manus is well documented from the sauropodomorphs to the derived titanosaurs, with phalanges vestigial or even absent in the latter $83,88,92-94$. It has been argued that the first pedal phalanx reduction events would occur in the two most lateral digits (IV and V). This process could be due to a functional compensation since the reduction of the lateral digits would occur at the same time as a greater growth of digits I and $\mathrm{II}^{95}$. Both processes may have occurred at the origin of the Neosauropoda clade and would also have affected the development of the ungual phalanges ${ }^{84,90}$.

Moreover, a brief review of skeletal feet (Fig. 7) is relevant for the discarding of some sauropod taxa and their corresponding clades. For instance, the Iniestapodus pes track morphology is different from those left by basal sauropods, such as Rhoetosaurus, which reveals four ungual phalanges, with the ungual of digit I the largest, and decreasing in size until digit IV; the ungual of digit I is located more anteriorly than the others, and the rest of the claws are oriented towards the anterior, lateral or lateroposterior ${ }^{86,96}$. Moreover, the Iniestapodus trackmaker differs from basal eusauropods that have three ungual phalanges, which are relatively large, and are anterolaterally oriented with a decreasing size from digit I to III ${ }^{50,97-99}$. In Eusauropoda, the impression of the claw in digit IV would be small (if present) ${ }^{46}$. These features can be seen in some Late Jurassic non-neosauropod eusauropods such as Janenschia ${ }^{91}$. Late Jurassic-Early Cretaceous turiasaurids (e.g., Turiasaurus, Mierasaurus) 

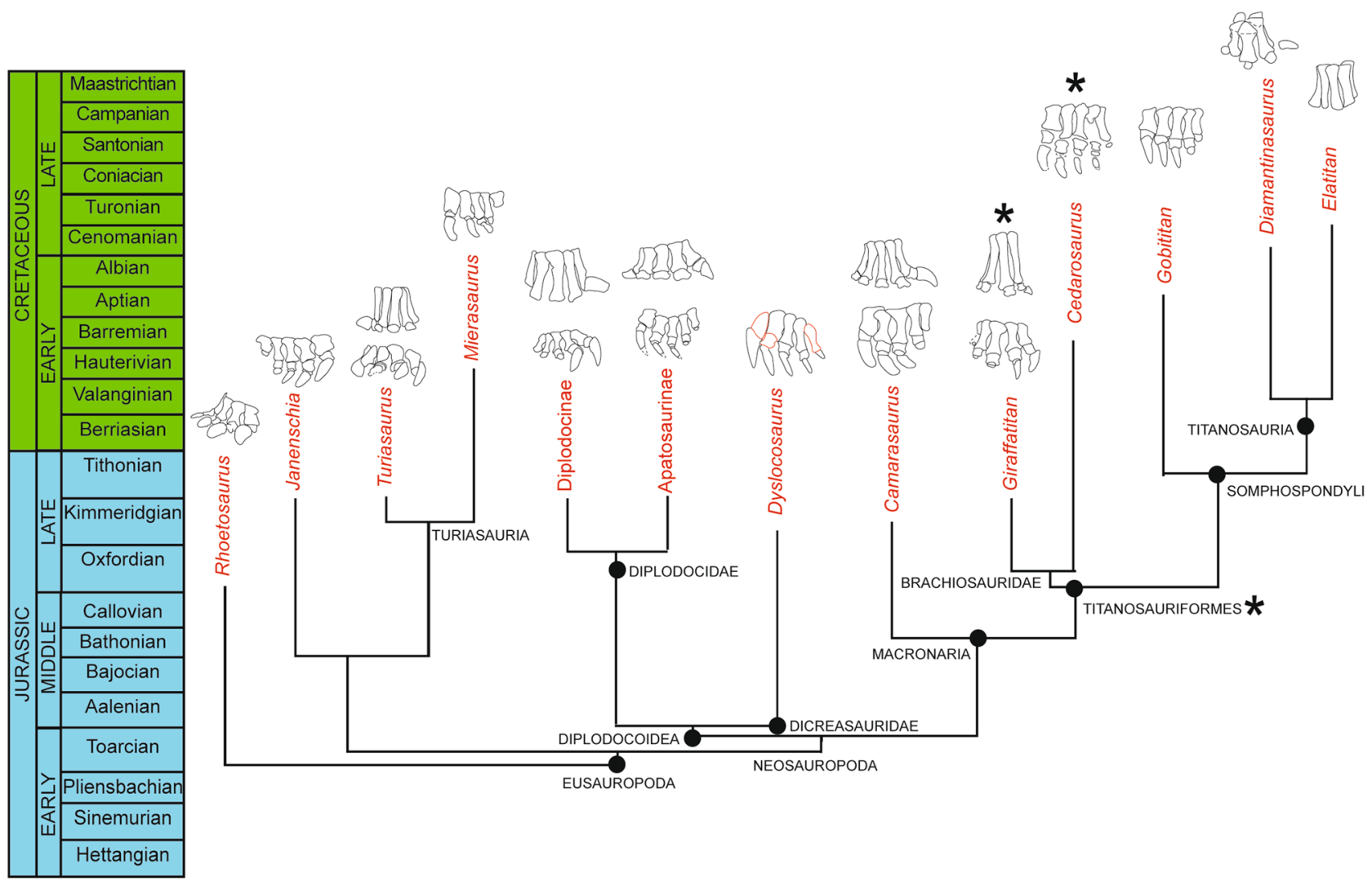

Figure 7. Simplified time-calibrated sauropod phylogenetic tree based on Mannion et al. ${ }^{91}$, with data from Tschopp et al. ${ }^{87}$ and Poropat et al. $^{88}$, showing complete manus and pes of selected Late Jurassic-Cretaceous taxa of each of the main clades. The clade that is proposed as the most probable trackmaker of Iniestapodus is marked with asterisks $\left(^{*}\right)$. Rhoetosaurus (pes redrawn from $^{96}$ ); Janenschia (pes redrawn from ${ }^{91}$ ); Turiasaurus (pes and manus redrawn from ${ }^{4}$ ); Mierasaurus (pes redrawn from ${ }^{100}$ ); Diplodocinae (pes of Diplodocus carnegii redrawn from ${ }^{101}$; manus of an indeterminate diplodocinae following ${ }^{102}$, redrawn from ${ }^{103}$ ); Apatosaurinae (pes of Apatosaurus louisae and manus of Brontosaurus parvus redrawn from ${ }^{104}$ ); Dicreasauridae (pes of Dyslocosaurus redrawn from ${ }^{105}$ ); Camarasaurus (pes of $C$. lentus redrawn and reversed from ${ }^{90}$, manus of Camarasaurus grandis (or sp) redrawn from ${ }^{106}$ see $^{94}$ ); Giraffatitan (manus redrawn from ${ }^{107}$, pes redrawn from ${ }^{96}$ ); Cedarosaurus (pes redrawn from ${ }^{108}$ ); Gobititan (pes redrawn from ${ }^{109}$ ); Diamantisaurus (manus redrawn from ${ }^{88}$ ); Elatitan (manus redrawn from $^{110}$ ).

also have three ungual phalanges (I-III), and a digit IV with just two phalanges and without a claw; ungual I is more developed than the other two, of which claw III is relatively small ${ }^{4,100}$. Within Neosauropods, pes impressions should be similar, with the main differences being in the number (two, three, or four) and the relative sizes of the pedal claws ${ }^{46}$.

Regarding diplodocoids, the articulated feet MB.R.2370 and MB.R.2371 from the Tithonian of the Tendanguru Beds and the feet of some Diplodocus Marsh, 1878 individuals from the Kimmeridgian-Tithonian Morrison Formation, show only two claws on digits I and II ${ }^{101,107,111}$. Moreover, the Late Jurassic Apatosaurus Marsh, 1877, and other diplodocine individuals show ungual phalanges on digits I-III, with I and II more developed than the III ${ }^{107,111}$. Digit IV lacks an ungual and is shorter than the other digits ${ }^{102-104,112}$. Within dicraeosaurs, Dyslocosaurus McIntosh et al., $1992^{105}$ preserved a foot with four claws that decrease in size from digit I to IV, and with an especially robust claw on digit I. The Late Jurassic macronarian Camarasaurus Cope, 1887 reveals well-developed claws on digits I through III, the claw I being larger than the other two, but the presence of a claw on digit IV is doubtful because the digit IV in Camarasaurus was short, with phalanges reduced in size ${ }^{87,113,114}$. Some Late Jurassic-Early Cretaceous non-titanosaurian titanosauriforms have three ungual phalanges, such as Tastavinsaurus ${ }^{115}$, Gobititan ${ }^{109}$, or an indeterminate titanosauriform from Russia ${ }^{116}$, whereas others, such as Cedarosaurus ${ }^{108,117}$, show four ungual phalanges. The pedes of the aforementioned non-titanosaurian titanosauriforms show claws with slightly decreasing sizes, but without large differences between them, particularly claw I with respect to claws II and III.

In summary, there are only two clear reports of neosauropods with four unguals on digits I-IV that fit with the morphological features of the pes tracks of Iniestapodus: the Early Cretaceous brachiosaurid Cedarosaurus ${ }^{108,117,118}$ and the dicraeosaurid Dyslocosaurus ${ }^{102,105}$. Additionally, it should be noted that Jensen ${ }^{113}$ reported a reduced fourth ungual phalanx in a pes of Camarasaurus, although other complete feet of this species only show three unguals $^{87,114}$. The former authors ${ }^{87}$ suggested that “...this underlines that the exact pedal phalangeal formula is still in question in many genera, and that this formula might be inter-or even intraspecifically variable". This highlights 


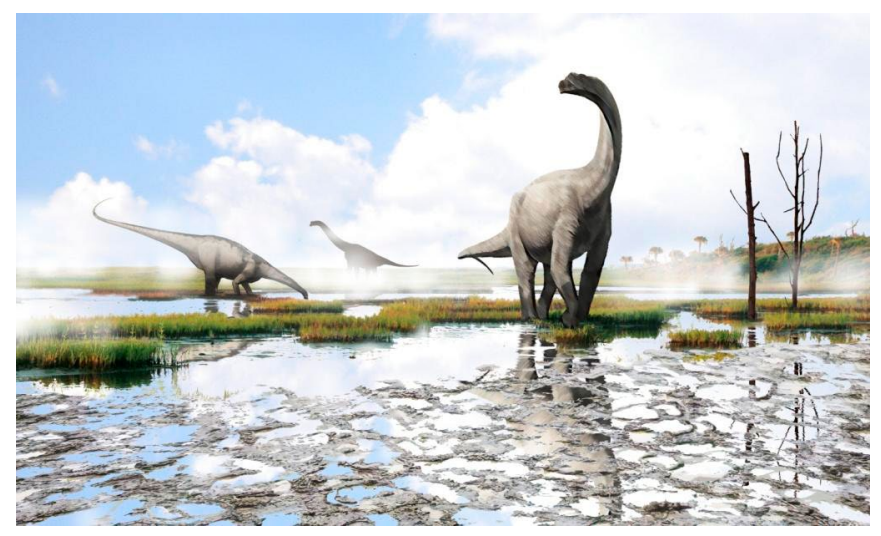

Figure 8. Paleoenvironmental reconstruction of the Las Sereas megatracksite. Illustration made with free software Autodesk SketchBook (https://www.autodesk.com/products/sketchbook/overview).

the difficulties in the identification of sauropod trackmakers based only on pes morphology. Finally, Cretaceous titanosaurs are characterized by a reduction in size or loss of pedal phalanges. They have three ungual phalanges with the digits I and II being generally similar in size, and with digit III being generally smaller or similar in size. Digit IV is much smaller than the other digits and lacks ungual phalanges ${ }^{46,85,89,119}$.

Despite the multi-source data provided by the pedal skeleton record, an analysis of sauropod manus osteology and the osteological record allows us to discard many of the aforementioned clades as potential trackmakers (Fig. 7). The manus morphology of Iniestapodus shows a small pollex impression that is key for identifying the sauropod clade. The sauropod fauna currently identified across the Jurassic-Cretaceous transition of the Iberian Peninsula include mainly non-neosauropod eusauropods (including turiasaurs), diplodocoids (some specimens with diplodocine affinities), basal macronarians (non-camarasaurids and camarasaurids), and brachiosaurid titanosauriform $s^{3,15}$. Many of these clades can be discarded from consideration since they have a very large pollex (Fig. 7) that presumably would leave a large impression ${ }^{51,94,106,114}$. Thus, eusauropods (including turiasaurs) ${ }^{4}$, some neosauropod clades such as camarasaurids ${ }^{87,113}$, and diplodocids ${ }^{103,104,106}$ could be discarded as a candidate trackmaker of Iniestapodus. Interestingly, the manus morphology of some titanosauriforms, such as the brachiosaurid Giraffatitan ${ }^{120}$ has a reduced pollex ${ }^{107,121}$. In general, the most derived titanosauriforms, the titanosaurs, reveal a loss of ungual phalanges in the manus ${ }^{110,122-124}$, with some exceptions (Diamantinasaurus ${ }^{88,93}$ ). Other groups, such as dicraeosaurids or titanosaurs, can be discarded since there is no record of their presence on the Iberian Peninsula or in Europe during this period.

Consequently, the analysis and comparison carried out between the anatomical characteristics preserved in the tracks (small ungual phalanx in the manual digit I, four ungual phalanges in the pes with unguals I and II sub-equal in size), and the sauropod bone record in the Iberian Peninsula suggest that titanosauriforms are the most plausible trackmakers. These data also fit with the predictions provided by Day et al. ${ }^{125}$ and Wright ${ }^{46}$. The former authors indicated that in brachiosaurids (and the most basal titanosaurs) the trackways should show intermediate-gauge and well-developed or reduced manus claw impressions. The presence of titanosauriforms on the Iberian peninsula is well-documented in the Jurassic-Cretaceous transition ${ }^{3,14,126-128}$, including a primitive brachiosaurid in the same deposits of the Rupelo Formation ${ }^{16}$, and thus this group of non-titanosaurian macronarians is the best candidate to have been the trackmaker of Iniestapodus. The only group that cannot be completely ruled out is the non-camarasaurid basal macronarians, since neither complete feet nor manus have been found; hence, there are no clear data regarding the trackway type of this sauropod group. Moreover, they co-occur in almost coeval deposits of the Iberian Range (e.g., Aragosaurus ${ }^{7,129}$ ), but with the current data, it is not possible to confidently consider them as plausible trackmakers.

Paleoecological and paleoenvironmental inferences. The Las Sereas tracksite is composed of several outcrops along a $5.6 \mathrm{~km}$ exposure of the top of the same horizon of lacustrine limestone strata. It covers an area of approximately $448,000 \mathrm{~m}^{2}$. The number of outcrops at Las Sereas is probably greater than the 14 tracksites currently known, because vegetation and debris partially conceal the track-bearing strata, and further prospecting is required ${ }^{130}$. A megatracksite is traditionally considered a regionally extensive track-bearing stratification surface with a lateral extension of hundreds or even thousands of meters ${ }^{19,131}$. Megatracksites are usually related to environments with large lateral extensions, such as coastal plains, tidal flats, or lacustrine settings ${ }^{19,131-136}$. Accordingly, Las Sereas can be considered a lacustrine megatracksite in a coastal wetland. It represents lowgradient lake margins in which seasonal lake level oscillations occurred. During the dry season in these coastal wetlands, the water would evaporate and only remain in the central parts of the lakes, creating a wide, exposed carbonate-mud plain undergoing progressive drying, with perfect conditions for impressing and preserving the tracks $^{30}$ (Fig. 8). This plain would have had concurrent areas with very soft and firm muds resulting in a mixture of deep and shallow, and well and poorly preserved tracks ${ }^{137}$. For instance, LS7 and LS8 are both on the same track-bearing surface and have tracks similar in size, but LS8 shows shallower tracks than LS7. It is possible that the substrate was drier when the LS8 trackway was registered than during the impressions of LS7. Moreover, 
although all the trackways preserve clear displacement rims, LS7 (see Fig. 3a-e) are more prominent than in LS8 (Figs. 2, 4). Similar lateral changes have been described in present-day tracks from tidal flats ${ }^{45,138}$.

Megatracksites can provide a broad spatial picture of the fauna present in an area ${ }^{19,131}$. The Las Sereas ichnoassociation is similar to those of other Laurasian Jurassic-Cretaceous units, comprising thyreophoran, sauropod, ornithopod, and theropod footprints ${ }^{18}$. It should be noted that almost all the sauropod tracks fall into two size categories: medium-sized (LS7A, LS7B, LS7C, LS8A) and small-sized (LS8B). The presence of tracks with the same shape and much smaller size (LSA8B) suggests that the trackmakers found at Las Sereas represent sauropods of two different ontogenetic stages ${ }^{137}$.

The orientation of the trackways may be evidence of gregarious behavior [e.g., ${ }^{1,47}$ ]. Nonetheless, in Las Sereas 7 the three analyzed trackways intersect each other with different directions of displacement (see Supplementary Fig. S2). In the extensive Las Sereas 8 site, the two studied trackways have different directions and are far from each other; in addition, several isolated sauropod tracks are arranged far from the two sauropod tracks of the site. Therefore, the possibility of gregarious behavior of the Iniestapodus trackmaker cannot be confidently inferred with the current data. Otherwise, the trackways indicate a random orientation pattern that represents directional or milling behaviour across the site ${ }^{1,139}$. The relative abundance of Iniestapodus at the Las Sereas megatracksite could indicate that the trackmaker used these shallow lacustrine/palustrine areas as its preferred habitat, as does the brachiosaurid registered in lower levels of the Rupelo Formation ${ }^{15}$.

\section{Conclusions}

The sauropod tracks studied herein were impressed in three exposures of the Las Sereas megatracksite, where more than 1000 vertebrate tracks, along $5.6 \mathrm{~km}$, have been identified at $\sim 14$ sites. They are preserved on the upper bedding plane surfaces of lacustrine strata from the upper part of the Rupelo Formation (Berriasian, Cameros Basin). The sauropod tracks belong to a new ichnotaxon Iniestapodus burgensis. Iniestapodus is characterized by subrectangular tetradactyl pes tracks with short claw I impression, forwardly oriented claw I and II impressions, and slightly rotated and curved laterally claw III and IV impressions. The manus tracks are semicircular to crescent shape, with three broad digit impression oriented posteriorly, and a short digit I impression medially located. Accordingly, non-titanosaurian titanosauriforms have been proposed as possible trackmakers, whereas other coeval quadrupedal dinosaurs (e.g., thyreophorans) are discarded. This group of sauropods, and brachiosaurids, particularly, are present in the Rupelo Formation as well as at other sites from the Jurassic-Cretaceous transition on the Iberian Peninsula. The only sauropod track morphotype present in the Las Sereas tracksite is Iniestapodus, which shows different track sizes and trackway orientations in the same outcrop and between outcrops. The data obtained here suggest that the trackmakers utilised shallow lacustrine/palustrine areas as their preferred habitat and that the trackways were produced by solitary individuals of different ontogenetic stages.

\section{Data availability}

The datasets generated during the current study are available from the corresponding author on reasonable request.

Received: 14 April 2021; Accepted: 23 July 2021

Published online: 20 August 2021

\section{References}

1. Castanera, D. et al. Sauropod trackways of the Iberian Peninsula: Palaeotological and palaeoenvironmental implications. J. Iber. Geol. 40(1), 49-59 (2014).

2. Castanera, D. et al. Iberian sauropod tracks through time: Variations in sauropod manus and pes track morphologies. In Dinosaur Tracks. The Next Steps (eds Falkingham, P. L. et al.) 120-137 (Indiana University Press, 2016).

3. Mocho, P., Royo-Torres, R., Malafaia, E., Escaso, F. \& Ortega, F. Sauropod tooth morphotypes from the Upper Jurassic of the Lusitanian Basin (Portugal). Pap. Palaeontol. 3(2), 259-295 (2017).

4. Royo-Torres, R., Cobos, A. \& Alcalá, L. A giant European dinosaur and a new sauropod clade. Science 314, 1925-1927 (2006).

5. Royo-Torres, R. et al. High european sauropod dinosaur diversity during Jurassic-Cretaceous transition in Riodeva (Teruel, Spain). Palaeontology 5(2), 1009-1027 (2009).

6. Dantas, P., Sanz, J.L., Marques da Silva, C., Ortega, F., Dos Santos, V.F. \& Cachao, M. Lourinhasaurus n. gen. Novo dinossáurio saurópode do Jurássico superior (Kimmeridgiano superior-Tithoniano inferior) de Portugal. V Congreso Nacional de Geología. 84(1.A), 91-94 (1998).

7. Sanz, J. L., Buscalioni, A. D., Casanovas, M. L. \& Santafé, J. V. Dinosaurios del Cretácico Inferior de Galve (Teruel, España). Est. Geol. 43, 45-64 (1987).

8. Lapparent, A. F. \& Zbyszewski, G. Les Dinosauriens du Portugal. Mém. Serv. Géol. Port. 1(2), 1-61 (1957).

9. Barco, J. L., Canudo, J. I., Cuenca-Bescós, G. \& Ruiz-Omeñaca, J. I. Un nuevo dinosaurio saurópodo Galvesaurus herreroi gen. nov., sp. nov., del tránsito Jurásico-Cretácico en Galve (Teruel, NE de España). Naturaleza Aragonesa. 15, 4-17 (2005).

10. Mocho, P., Royo-Torres, R. \& Ortega, F. A new macronarian sauropod from the Upper Jurassic of Portugal. J. Verteb. Paleontol. (2019). https://doi.org/10.1080/02724634.2019.1578782

11. Bonaparte, J. F. \& Mateus, O. A new diplodocid, Dinheirosaurus lourinhanensis gen. et sp. nov., from the Late Jurassic beds of Portugal. Rev. Mus. Argent. Cienc. Nat. 5(2), 13-29 (1999).

12. Casanovas, M. L., Santafé, J. V. \& Sanz, J. Losillasaurus giganteus, un nuevo saurópodo del tránsito Jurásico-Cretácico de la cuenca de "Los Serranos" (Valencia, España). Paleontologia i Evolució. 32-33, 99-122 (2001).

13. Mateus, O., Mannion, P. D. \& Upchurch, P. Zby atlanticus, a new turiasaurian sauropod (Dinosauria, Eusauropoda) from the Late Jurassic of Portugal. J. Verteb. Paleontol. 43(3), 618-634 (2014).

14. Canudo, J. I., Barco, J. L., Castanera, D. \& Torcida Fernández-Baldor, F. New record of a sauropod in the Jurassic-Cretaceous transition of the Iberian Peninsular (Spain): Palaeobiogeographical implications. PalZ. 84, 427-435 (2010).

15. Torcida Fernández-Baldor, F., Canudo, J. I. \& Huerta, P. New data on sauropod palaeobiodiversity at the Jurassic-Cretaceous transition of Spain (Burgos). J. Iber. Geol. 46, 351-362 (2020).

16. Platt, N. H. \& Meyer, C. A. Dinosaur footprints from the Lower Cretaceous of Northern Spain: Their sedimentological and palaeontological context. Palaeogeogr. Palaeoclimatol. Palaeoecol. 86, 321-333 (1991). 
17. Torcida Fernández-Baldor, F. et al. Estudio previo del yacimiento de icnitas de dinosaurios de Las Sereas (Cuenca de Cameros, Jurásico Superior-Cretácico Inferior). In Actas de V Jornadas Internacionales sobre Paleontología de Dinosaurios y su Entorno (eds Torcida Fernández-Baldor, F. et al.) 197-204 (Colectivo Arqueológico y Paleontológico de Salas, 2012).

18. Torcida Fernández-Baldor, F. et al. Unusual sauropod track in the Jurassic-Cretaceous interval of the Cameros Basin (Burgos, Spain). J. Iber. Geol. 41(1), 141-154 (2015).

19. Lockley, M. G. Tracking Dinosaurs: A New Look at an Ancient World (Cambridge University Press, 1991).

20. Salas, R. et al. Evolution of the Mesozoic Central Iberian Rift System and its Cainozoic inversion (Iberian chain). In Peri-Tethys Memoir 6: Peri-tethyan Rift/Wrench Basins and Passive Margins (eds Ziegler, P. A. et al.) 145-186 (Mémoires du Museum National d'Histoire Naturelle, 2001).

21. Aurell, M. et al. Kimmeridgian-Berriasian stratigraphy and sedimentary evolution of the central Iberian Rift System (NE Spain). Cretaceous Res. 103, 104153 (2019).

22. Mas, R. et al. Coastal wetlands as markers of transgression in proximal extensional systems (Berriasian, W Cameros Basin, Spain). J. Iber. Geol. 45, 1-27 (2019).

23. Platt, N. H. Sedimentology and tectonics of the western Cameros basin. Province of Burgos, Northern Spain. Unpublished Master Thesis. University of Oxford, 250 (1986).

24. Clemente, P. Review of the Upper Jurassic-Lower Cretaceous Stratigraphy in Western Cameros basin, Northern Spain. Rev. Soc. Geol. Esp. 23(3-4), 101-143 (2010).

25. Clemente, P. \& Pérez-Arlucea, M. Depositional architecture of the Cuerda del Pozo Formation, Lower Cretaceous of the Extensional Cameros Basin, North-Central Spain. J. Sediment. Petrol. 63, 437-452 (1993).

26. Martín-Closas, C. \& Alonso Millán, A. Estratigrafía y bioestratigrafía (Charophyta) del Cretácico inferior en el sector occidental de la Cuenca de Cameros (Cordillera Ibérica). Rev. Soc. Geol. España. 11, 253-270 (1998).

27. Schudack, U. \& Schudack, M. Ostracod biostratigraphy in the Lower Cretaceous of the Iberian chain (eastern Spain). J. Iber. Geol. 35(2), 141-168 (2009).

28. Platt, N. Continental sedimentation in an evolving rift basin: The lower Cretaceous of the western Cameros Basin (northern Spain). Sed. Geol. 64, 91-109 (1989).

29. Schudack, M. Charophyten flora und fazielle Entwicklung der Grenzschichten mariner Jura/Wealden in den Nordwestlichen Iberischen Ketten (mit Vergleichen Asturien und Kantabrien). Palaeontogr. Abt. B-Palaophytol. 204 1-180, (1987).

30. Platt, N. H. Lacustrine carbonates and pedogenesis-Sedimentology and Origin of Palustrine deposits from the Early Cretaceous Rupelo Formation, W Cameros Basin, N Spain. Sedimentology 36(4), 665-684 (1989).

31. Casanovas Cladellas, M. L., Fernández Ortega, A., Pérez-Lorente, F. \& Santafé Llopis, J. V. Huellas de dinosaurio de La Rioja. Yacimientos de Valdecevillo, La Senoba y de la Virgen del Campo (ed. Instituto de Estudios Riojanos) Ciencias de la Tierra. 12, 190 (1989).

32. Pérez-Lorente, F. Icnitas de dinosaurios del Cretácico en España. In Dinosaurios y Otros Reptiles Mesozoicos de España (ed. Pérez-Lorente, F.) 49-108 (Instituto de Estudios Riojanos, 2003).

33. Torcida Fernández-Baldor, F. et al. Un extenso yacimiento de icnitas de dinosaurios del tránsito Jurásico Superior-Cretácico Inferior de Burgos. In Libro de Resúmenes. XXII Jornadas de la Sociedad Española de Paleontología (ed. Fernández-Martínez, E.) 185-187 (Universidad de León, 2006).

34. Falkingham, P. L. Acquisition of high resolution 3D models using free, open-source, photogrammetric software. Palaeontol. Electron. 15(1;1T), 15 (2012).

35. Mallison, H. \& Wings, O. Photogrammetry in paleontology-A practical guide. J. Paleontol. $l$ Tech. 12, 1-31 (2014).

36. Falkingham, F. L. et al. A standard protocol for documenting modern and fossil ichnological data. Palaeontology 61, 469-480 (2018).

37. Leonardi, G. Glosary and Manual of Tetrapod Footprint Palaeoichnology (Departmento Nacional de Producao Mineral, 1987).

38. Farlow, J. O., Pittman, J. F. \& Hawthorne, J. M. Brontopodus birdi, Lower Cretaceous Sauropod footprints from the US Gulf Coastal Plain. In Dinosaur Tracks and Traces (eds Gillette, D. D. \& Lockley, M. G.) 371-393 (Cambridge University Press, 1989).

39. Thulborn, T. Dinosaur Tracks (Chapman and Hall, 1990).

40. Lockley, M. G., Farlow, J. O. \& Meyer, C. A. Brontopodus and Parabrontopodus ichnogen nov. and the significance of wide- and narrow-gauge sauropod trackways. Gaia 10, 135-145 (1994).

41. González Riga, B. \& Calvo, J. O. A new wide-gauge sauropod track site from the Late Cretaceous of Mendoza, Neuquén Basin, Argentina. Palaeontology 52(3), 631-640 (2009).

42. Romano, M., Whyte, M. A. \& Jackson, S. J. Trackway Ratio: A new look at trackway gauge in the analysis of quadrupedal dinosaur trackways and its implications for icnotaxonomy. Ichnos 14, 257-270 (2007).

43. Marty, D. et al. Comparative analysis of Late Jurassic sauropod trackways from the Jura Mountains (NW Switzerland) and the central High Atlas Mountains (Morocco): Implications for sauropod ichnotaxonomy. Hist. Biol. 22(1-3), 109-133 (2010).

44. Marchetti, L. et al. Defining the morphological quality of fossil footprints. Problems and principles of preservation in tetrapod ichnology with examples from the Palaeozoic to the present. Earth Sci. Rev. 193, 109-145 (2019).

45. Marty, D. Sedimentology, taphonomy, and ichnology of Late Jurassic dinosaur tracks from the Jura carbonate platform (ChevenezCombe Ronde tracksite, NW Switzerland): Insights into the tidal-flat palaeoenvironment and dinosaur diversity, locomotion, and palaeoecology. Ph Thesis. Université de Fribourg, 286 (2008).

46. Wright, J. L. Steps in understanding sauropod biology: The importance of sauropod tracks. In The Sauropods: Evolution and Paleobiology (eds Curryrogers, K. A. \& Wilson, J. A.) 252-284 (University of California Press, 2005).

47. Castanera, D., Barco, J. L., Díaz-Martínez, I., Pérez-Lorente, F. \& Canudo, J. I. New evidence of a herd of titanosauriform sauropods from the Lower Berriasian of the IberianRange (Spain). Paleogeogr. Paleoclimatol. Paleoecol. 310, 227-237 (2011).

48. Kim, H. Y. \& Lockley, M. G. New sauropod tracks (Brontopodus pentadactylus ichnosp. nov.) from the Early Cretaceous Haman Formation of Jinju Area, Korea: Implications for sauropods manus morphology. Ichnos 19, 84-92 (2012).

49. Díaz-Martínez, I., Pereda-Suberbiola, X., Pérez-Lorente, F. \& Canudo, J. I. Ichnotaxonomic review of large ornithopod dinosaur tracks: Temporal and geographic implications. PLoS ONE 10(2), e0115477 (2015).

50. Carrano, M. T. \& Wilson, J. A. Taxon distributions and the tetrapod track record. Paleobiology 27(3), 564-582 (2001).

51. Farlow, J. O. Sauropod tracks and trackmarkers: Integrating the ichnological and skeletal records. Zubía. 10, 89-138 (1992).

52. McCrea, R. T. The Distribution of Vertebrate Ichnotaxa from Lower Cretaceous (Albian) Gates Formation Tracksites Near Grande Cache, Alberta: Implications for Habitat Preference And Functional Pedal Morphology (Alberta Palaeontological Society, 2001).

53. Hornung, J. J. \& Reich, M. Metatetrapous valdensis Nopcsa, 1923 and the presence of ankylosaur tracks (Dinosauria: Thyreophora) in the Berriasian (Early Cretaceous) of Northwestern Germany. Ichnos 21(1), 1-18 (2014).

54. Nopcsa, B. Notes on British Dinosaurs. Part VI: Acanthopholis. Geol. Mag. 60(5), 193-199 (1923).

55. Sternberg, C. M. Dinosaur tracks from Peace River, British Columbia. Ann. Rep. Nati. Mus. Canada. 1930, 59-85 (1932).

56. Whyte, M. A. \& Romano, M. Probable sauropod footprints from the Middle Jurassic of Yorkshire, England. Gaia 10, 15-26 (1995)

57. Cobos, A., Royo-Torres, R., Luque, L., Alcalá, L. \& Mampel, L. An iberian stegosaurs paradise: The Villar del Arzobispo Formation (Tithonian-Berriasian) in Teruel (Spain). Palaeogeogr. Palaeoclim. Palaeoecol. 293, 223-236 (2010).

58. Pascual, C., Canudo, J. I., Hernández, N., Barco, J. L. \& Castanera, D. First record of stegosaur dinosaur tracks in the Lower Cretaceous (Berriasian) of Europe (Oncala group, Soria, Spain). Geodiversitas. 34(2), 297-312 (2012). 
59. Hitchcock, E. Description of two new species of fossil footmarks found in Massachusetts and Connecticut, or, of the animals that made them. Am. J. Sci. 4(2), 46-57 (1847).

60. Ellenberger, P. Contribution à la classification des Pistes de Vertébrés du Trias: Les types du Stormberg d’Afrique du Sud (I). Palaeovertebrata, Mémoire Extraordinaire, 104 (Centre National de La Recherche Scientifique, Montpellier, 1972).

61. Gand, G., Vianey-Liaud, M., Demathieu, G. \& Garric, J. Deux nouvelles traces de pas de dinosaures du Trias Supérieur de la bordure cévenole (La grand-combe, sud-est de la France). Geobios 33(5), 599-624 (2000).

62. D’Orazi Porchetti, S. \& Nicosia, U. Re-examination of some large early Mesozoic tetrapod footprints from the African collection of Paul Ellenberger. Ichnos 14(3-4), 219-245 (2007).

63. Masrour, M. \& Pérez-Lorente, F. Otozoum trackway in Issil-n-AitArbi (Lower Jurassic, Central High Atlas, Morocco). Geogaceta 56, 107-110 (2014).

64. Kaever, M. \& de Lapparent, A. F. Les traces de pas de dinosaures du Jurassique de Barkhausen (Basse Saxe, Allemagne). Bull. Soc. Géol. France. 7, 516-525 (1974).

65. Hendricks, A. Die Saurierfährten von Münchehagen bei Rehburg-Loccum (NWDeutschland). Abhandlungen des Landesmuseum für Naturkunde Münster. 43, 1-22 (1981).

66. Mensink, H. \& Mertmann, D. Dinosaurier-Fährten (Gigantosauropus asturensis n.g. n. sp.; Hispanosauropus hauboldi n.g. n. sp.) im Jura Asturiensis bei La Griega und Ribadesella (Spanien). Neues Jb. Geol. Paläontol. Monat. 1984, 405-415 (1984).

67. Calvo, J. O. Huellas de dinosaurios en la Formación Río Limay (Albiano-Cenomaniano?), Picun Leufu, Provincia de Neuquén, República Argentina. (Ornithischia-Saurischia: Sauropoda-Theropoda). Ameghiniana 28, 241-258 (1991).

68. Meyer, C. A., Marty, D. \& Belvedere, M. Titanosaur trackways from the late cretaceous el molino Formation of Bolivia (Cal orcko, sucre). Annales Societatis Geologorum Polonia. 88, 223-241 (2018).

69. Lockley, M. G., Wright, J. L. \& Thies, D. Some observations on the dinosaur tracks at Münchehagen (Lower Cretaceous), Germany. Ichnos 11(3-4), 261-274 (2004).

70. Lockley, M. G., Lires, J., García-Ramos, J. C., Pinuela, L. \& Avanzini, M. Shrinking the world's largest dinosaur tracks: Observations on the ichnotaxonomy of Gigantosauropus asturiensis and Hispanosauropus hauboldi from the Upper Jurassic of Asturias, Spain. Hist Biol. 14(3-4), 247-255 (2007).

71. Ishigaki, S. \& Matsumoto, Y. "Off- tracking"-like phenomenon observed in the turning sauropod trackway from the Upper Jurassic of Morocco. Memoir of the Fukui Prefectural Dinsoaur Museum. 8, 1-10 (2009).

72. Lockley, M. et al. The first sauropod trackways from China. Cretaceous Res. 23, 363-381 (2002).

73. Mazin, J. M., Hantzpergue, P. \& Olivier, N. The dinosaur tracksite of Plagne (early Tithonian, Late Jurassic; Jura Mountains, France): the longest known sauropod trackway. Geobio. 50, 279-301 (2017).

74. Salisbury, S. W., Romilio, A., Herne, M. C., Tucker, R. T. \& Nair, J. P. The dinosaurian ichnofauna of the lower cretaceous (Valanginian-Barremian) broome sandstone of the Walmadany area (James Price Point), Dampier Peninsula, Western Australia. J. Vertebr. Paleontol. 36(sup1), 1-152 (2016).

75. Moreau, J. D. et al. Middle Jurassic tracks of sauropod dinosaurs in a deep karst cave in France. J. Vertebr. Paleontol. 39, e1728286 (2019).

76. Dalla Vecchia, F. M. \& Tarlao, A. New dinosaur tracks sites in the Albian (Early Cretaceous) of the Istrian peninsula (Croatia). Parte II-Paleontology. Memorie di Scienze Geologische. 52, 227-292 (2000).

77. Meijide Fuentes, F., Fuentes Vidarte, C., Meijide Calvo, M., \& Meijide Fuentes, M. Rastro de un dinosaurio Saurópodo en el Weald de Soria (España) Brontopodus oncalensis nov. Icnsp. Celtiberia. 98, 501-515 (2004).

78. Moreno, K. \& Benton, M. J. Occurrence of sauropod dinosaur tracks in the Upper Jurassic of Chile (redescription of Iguanodonichnus frenki). J. S. Am. Earth Sci. 20(3), 253-257 (2005).

79. Santos, V. F., Moratalla, J. F. \& Royo-Torres, R. New sauropod trackways from the Middle Jurassic of Portugal. Acta Palaeontol. Pol. 54(3), 409-422 (2009).

80. Dutuit, J. M. \& Ouazzou, A. Découverte d'une piste de Dinosaure sauropode sur le site d'empreintes de Demnat (Haut-Atlas marocain). Mémoires de la Société Géologique de France, Nouvelle Série. 139, 95-102 (1980).

81. Cheng, S. \& Huang, X. Preliminary study of dinosaur tracks in Changling, Chuxiong Prefecture. J. Yunnan Geol. 12, 266-276 (1993).

82. Casamiquela, R. M. \& Fasola, A. Sobre pisadas de dinosaurios del Cretácico Inferior de Colchagua (Chile). Universidad de Chile, Departamento de Geología. 30, 1-24 (1968).

83. Borsuk-Bialynicka, M. A new camarasaurid sauropod Opisthocoelicaudia skarzynskii gen. n., sp. n. from the Upper Cretaceous of Mongolia. Acta Palaeontol. Pol. 37, 5-64 (1977).

84. Upchurch, P. The Phylogenetic Relationships of Sauropod Dinosaurs. Zool. J. Linn. Soc. 124, 43-103 (1998).

85. Bonnan, M. F. Pes anatomy in sauropod dinosaurs: Implications for functional morphology, evolution, and phylogeny. In Thunder-Lizards. The Sauropodomorph Dinosaurs (eds Tidwell, V. \& Carpenter, K.) 346-380 (Indiana University Press, 2005).

86. Nair, J. P. \& Salisbury, S. W. New anatomical information on Rhoetosaurus brownei Longman, 1926, a gravisaurian sauropodomorph dinosaur from the Middle Jurassic of Queensland, Australia. J. Vertebr. Paleontol. 32(2), 369-394 (2012).

87. Tschopp, E., Wings, O., Frauenfelder, T. \& Brinkmann, W. A. Articulated bone sets of manus and pedes of Camarasaurus (Sauropoda, Dinosauria). Palaeontol. Electron. 18(2, 44 A), 1-65 (2015).

88. Poropat, S. F. et al. Revision of the sauropod dinosaur Diamantinasaurus matildae Hocknull et al from. 2009 the mid-Cretaceous of Australia: Implications for Gondwanan titanosauriform dispersal. Gondwana Res. 27, 995-1033 (2015).

89. González Riga, B., Calvo, J. O. \& Porfiri, J. An articulated titanosaur from Patagonia (Argentina): New evidence of neosauropod pedal evolution. Palaeoworld 17, 33-40 (2008).

90. González Riga, B. J., Lamanna, M. C., Ortiz David, L. D., Calvo, J. O. \& Coria, J. P. A gigantic new dinosaur from Argentina and the evolution of the sauropod hind foot. Sci. Rep. 6, 19165 (2016).

91. Mannion, P. D., Upchurch, P., Schwarz, Z. \& Wings, O. Taxonomic affinities of the putative titanosaurs from the Late Jurassic Tendaguru Formation of Tanzania: Phylogenetic and biogeographic implications for eusauropod dinosaur evolution. Zool. J. Linn. Soc. XX, 1-126 (2019).

92. Martínez, R. D., Giménez, O., Rodríguez, J., Luna, M. \& Lamanna, M. C. An articulated specimens of the basal titanosaurian (Dinosauria: Sauropoda) Epachthosaurus sciuttoi from the early late Cretaceous Bajo Barreal Formation of Chubut Province, Argentina. J. Vertebr. Paleontol. 24(1), 107-120 (2004).

93. Hocknull, S. A. et al. New mid-cretaceous (Latest Albian) dinosaurs from Winton, Queensland, Australia. PLoS ONE 4(7), e6190 (2009).

94. Bonnan, M. F. The evolution of manus shape in sauropod dinosaurs: Implications for functional morphology, forelimb orientation, and phylogeny. J. Vertebr. Paleontol. 23(3), 595-613 (2003).

95. Lockley, M. G. The morphodynamics of dinosaurs, other archosaurs and their trackways: Holistic insights into relationships between feet, limbs and the whole body. In Ichnology at the Crossroads: A Multidimensional Approach to the Science of Organism-Substrate Interactions Vol. 88 (eds Bromley, R. \& Melchor, R.) 27-51 (Society of Economic Paleontologists and Mineralogists Special Publication, 2007).

96. Jannel, A. et al. "Keep your feet on the ground": Simulated range of motion and hind foot posture of the Middle Jurassic sauropod Rhoetosaurus brownei and its implications for sauropod biology. Int. J. Morphol. https://doi.org/10.1002/jmor.209892019 (2019). 
97. Young, C. C. On a new Sauropoda, with notes on other fragmentary Reptilia from Szechuan. Bull. Geol. Soc. China. 19, 279-315 (1939).

98. Dong, Z., Zhou, S. \& Zhang, Y. The dinosaurian remains from Sichuan Basin, China. Palaeont. Sin. 162(C, 23), 1-145 (1983).

99. Wilson, J. A. Integrating ichnofossil and body fossil records to estimate locomotor posture and spatiotemporal distribution on early sauropod dinosaurs: A strato cladistic approach. Paleobiology 31(3), 400-423 (2005).

100. Royo-Torres, R. et al. Descendants of the Jurassic turiasaurs from Iberia found refuge in the Early Cretaceous of western USA. Sci. Rep. 7, 14311. https://doi.org/10.1038/s41598-017-14677-2 (2017).

101. Hatcher, J. B. Diplodocus (Marsh): Its osteology, taxonomy and probable habits, with a restoration of the skeleton. Mem. Carnegie Mus. 1, 63 (1901).

102. Tschopp, E. et al. A specimen-level phylogenetic analysis and taxonomic revision of Diplodocidae (Dinosauria, Sauropoda). PeerJ 3, e857. https://doi.org/10.7717/peerj.857 (2015).

103. Bedell, M. W. \& Trexler, D. L. First articulated manus of Diplodocus carnegii. In Thunder-Lizards. The Sauropodomorph Dinosaurs (eds Tidwell, V. \& Carpenter, K.) 302-320 (Indiana University Press, 2005).

104. Gilmore, C. W. Osteology of Apatosaurus with special reference to specimens in the Carnegie Museum. Mem. Carnegie Mus. 11, 175-300 (1936).

105. McIntosh, J. S., Coombs, W. P. \& Russell, D. A. A new diplodocid sauropod (Dinosauria) from Wyoming, USA. J. Paleontol. 12(2), 158-167 (1992).

106. Osborn, H. F. Manus, sacrum and caudals of Sauropoda. Bull. Am. Mus. Nat. His. 20, 181-190 (1904).

107. Janensch, W. Skelett rekonstruktion von Dysalotosaurus lettow-vorbecki. Palaeontographica Supplementbände. 177-235(1961).

108. D'Emic, M. D. Revision of the sauropod dinosaurs of the Lower Cretaceous Trinity Group, southern USA, with the description of a new genus. J. Syst. Palaeontol. https://doi.org/10.1080/14772019.2012.667446 (2012).

109. You, H., Tang, F. \& Luo, Z. A new basal titanosaur (Dinosauria: Sauropoda) from the Early Cretaceous of China. Acta Geol. Sin. 77(4), 424-429 (2003)

110. Mannion, P. D. \& Otero, A. A reappraisal of the Late Cretaceous Argentinean sauropod dinosaur Argyrosaurus superbus, with a description of a new titanosaur genus. J. Vertebr. Paleontol. 32(3), 614-638 (2012).

111. Remes, K. Taxonomy of Late Jurassic diplodocid sauropods from Tendaguru (Tanzania). Fossil Record. 12(1), 23-46 (2009).

112. Holland, W. J. A review of some recent criticisms on the restorations of sauropod dinosaurs existing in the museums of the United States, with special reference to that of Diplodocus carnegiei in the Carnegie Museum. Am. Nat. 44, 259-283 (1910).

113. Jensen, J. A. A fourth new sauropod dinosaur from the Upper Jurassic of the Colorado Plateau and sauropod bipedalism. Great Basin Naturalist. 48(2), 121-145 (1988).

114. Farlow, J. O. A Guide to Lower Cretaceous Dinosaur Footprints and Tracksites of Paluxy River Valley, Somervell County, Texas 50 (South Central G.S.A., Baylor University, 1987).

115. Royo-Torres, R., Alcalá, L. \& Cobos, A. A new specimen of the Cretaceous sauropod Tastavinsaurus sanzi from El Castellar (Teruel, Spain), and a phylogenetic analysis of the Laurasiformes. Cretac. Res. 34, 61-83 (2012).

116. Averianov, A. O., Voronkevich, A. V., Maschenko, E. N., Leshchinskyi, S. V. \& Fayngertz, A. V. A sauropod foot from the Early Cretaceous of Western Siberia, Russia. Acta Palaeontol. Pol. 47(1), 117-124 (2002).

117. Gallup, M. R. Functional morphology of the hindfoot of the Texas sauropod Pleurocoelus sp. indet. In Paleobiology of the Dinosaurs (ed. Farlow, O.) 71-74 (Geological Society of America Special Paper, 1989).

118. Tidwell, V., Carpenter, K. \& Brooks, W. New sauropod from the Lower Cretaceous of Utah, USA. Oryctos. 2(21), 21-37 (1999).

119. Wilson, J. A. Sauropod dinosaur phylogeny: Critique and cladistic analysis. Zool. J. Linn. Soc. 136(2), 215-275 (2002).

120. Paul, G. S. The brachiosaur giants of the Morrison and Tendaguru with a description of a new subgenus, Giraffatitan, and a comparison of the world's largest dinosaurs. Hunteria. 2(3), 1-14 (1988).

121. Janensch, W. Das Handskelett von Gigantosaurus robustus und Brachiosaurus brancai aus den Tendaguru-Schichten DeutschOstafrikas. Centralb Mineral. Geol. Paläontol. 464-480 (1922).

122. Salgado, L., Coria, R. A. \& Calvo, J. O. Evolution of titanosaurid sauropods. I: Phylogenetic analysis based on the postcranial evidence. Ameghiniana 34(1), 3-32 (1997).

123. Wilson, J. A. \& Sereno, P. C. Early evolution and higher-level phylogeny of sauropod dinosaurs. J. Vertebr. Paleontol. 18(Supl. 2), 1-68 (1998).

124. Day, J. J. et al. Sauropod trackways, evolution, and behavior. Science 296, 1659 (2002).

125. Day, J. J., Norman, D. B., Gale, A. S., Upchurch, P. \& Powell, P. A middle Jurassic dinosaur trackway site from Oxfordshire, UK. Palaeontology 47(2), 319-348 (2004).

126. Antunes, M. T. \& Mateus, O. Dinosaurs of Portugal. C R Palevol. 2(1), 77-95 (2003)

127. Mannion, P. D., Upchurch, P., Barnes, R. N. \& Mateus, O. Osteology of the Late Jurassic Portugese sauropod dinosaur Lusotitan atalaiensis (Macronaria) and the evolutionary history of basal titanosauriformes. Zool. J. Linn. Soc. 168, 98-206 (2013).

128. Pérez-Pueyo, M., Moreno-Azanza, M., Barco, J. L. \& Canudo, J. I. New contributions to the phylogenetic position of the sauropod Galvesaurus herreroifrom the Tithonian (Jurassic) of Spain (Teruel). Bol. Geol. Min. 130(3), 375-392 (2019).

129. Royo-Torres, R. et al. The anatomy, phylogenetic relationships, and stratigraphic position of the Tithonian-Berriasian Spanish sauropod dinosaur Aragosaurus ischiaticus. Zool. J. Linn. Soc. 171(3), 623-655 (2014).

130. Torcida Fernández-Baldor, F. et al. Estudio previo del yacimiento de icnitas de dinosaurios de Las Sereas (Cuenca de Cameros, Jurásico Superior-Cretácico Inferior). In Actas de V Jornadas Internacionales sobre Paleontología de Dinosaurios y su Entorno (eds Torcida Fernández-Baldor, F. et al.) 197-204 (Colectivo Arqueológico y Paleontológico de Salas, 2012).

131. Lockley, M. G. The paleoecological and paleoenvironmental utility of dinosaur tracks. In The Complete Dinosaur (eds Farlow, J. O. \& Brett-Surman, M. K.) 554-578 (Indiana University Press, 1997).

132. Meyer, C. A sauropod dinosaur megatracksite from the Late Jurassic on northern Switzerland. Ichnos 3, 29-38 (1993).

133. Moratalla, J. J. \& Sanz, J. L. Cameros Basin Megatracksite. In Encyclopedia of Dinosaurs (eds Currie, P. J. \& Padian, K.) 87-89 (Academic Press, 1997).

134. Kvale, E. P. et al. Middle Jurassic (Bajocian and Bathonian) dinosaur megatracksites, Bighorn Basin, Wyoming, USA. Palaios 16, 233-254 (2001).

135. Diedrich, C. New important iguanodontid and theropod trackways of the tracksite Obernkirchen in the Berriasian of NW Germany and Megatracksite concept of Central Europe. Ichnos 11, 215-228 (2004).

136. Navarrete, R. et al. A thick Tethyan multi-bed tsunami deposit preserving a dinosaur megatracksite within a coastal lagoon (Barremian, eastern Spain). Sed. Geol. 313, 105-127 (2014).

137. Díaz-Martínez, I. et al. Multi-aged social behaviour based on artiodactyl tracks in an early Miocene palustrine wetland (Ebro Basin, Spain). Sci. Rep. 10, 1099 (2020).

138. Jackson, S. J., Whyte, M. A. \& Romano, M. Range of experimental dinosaur (Hypsilophodon foxii) footprints due to variation in sand consistency: How wet was the track?. Ichnos 17, 197-214 (2010).

139. Cohen, A. S., Halfpenny, J., Lockley, M. \& Michel, E. Modern vertebrate tracks from Lake Manyara, Tanzania and their paleobiological implications. Paleobiology 19(4), 433-458 (1993). 


\title{
Acknowledgements
}

The cleaning, excavation, consolidation, protection and conservation works at the Las Sereas sites (3, 7 and 8) have been possible thanks to funding from the Fundación para el Estudio de los dinosaurios en Castilla y León, Red Eléctrica de España, Diputación de Burgos and Caja de Burgos and La Caixa (Obra Social). The municipalities of Quintanilla de las Viñas, Salas de los Infantes and Quintanalara, and various Burgos private businesses have also collaborated. The CENIEH (Centro Nacional de Investigación sobre la Evolución Humana) scanned the Las Sereas 7 and Las Sereas 8 sites. Special thanks to all those who have participated in the field work carried out on the Las Sereas sites from 2009 until 2020. DC has been supported by the Beatriu de Pinós postdoctoral programme (BP2017-00195) of the Government of Catalonia's Secretariat for Universities and by the Spanish Ministerio de Economía y Competitividad-ERDF (Project CGL2017-85038-P) and the Spanish Ministerio de Ciencia Innovación y Universidades (Project PGC2018-094566-B-C2). The manuscript has been greatly improved thanks to the comments of Lara Sciscio, and the reviews of Martin G. Lockley and Anthony Martin.

\section{Author contributions}

F.T.F.-B. participated in the field work and graphic documentation of the studied sites, the design of the work, the acquisition, analysis, and interpretation of data, in the preparation and creation of the work, critical review, commentary, and revision. I.D.M. participated in the design of the work, the acquisition, analysis, and interpretation of data, creation of photogrammetric models, the preparation and creation of the work, critical review, commentary, and revision. P.H. participated in the field work, the design of the work, the analysis, and interpretation of data, in the preparation and creation of the work, critical review, commentary, and revision. D.M.H. participated in the field work and graphic documentation of the studied sites, prepared figures, the design of the work, and participated in the preparation of the work. D.C. participated in the design of the work, the analysis, and interpretation of data, creation of photogrammetric models, the preparation of the work, critical review, commentary, and revision.

\section{Competing interests}

The authors declare no competing interests.

\section{Additional information}

Supplementary Information The online version contains supplementary material available at https://doi.org/ 10.1038/s41598-021-95675-3.

Correspondence and requests for materials should be addressed to F.T.-B.

Reprints and permissions information is available at www.nature.com/reprints.

Publisher's note Springer Nature remains neutral with regard to jurisdictional claims in published maps and institutional affiliations.

\begin{abstract}
(c) (i) Open Access This article is licensed under a Creative Commons Attribution 4.0 International cc) License, which permits use, sharing, adaptation, distribution and reproduction in any medium or format, as long as you give appropriate credit to the original author(s) and the source, provide a link to the Creative Commons licence, and indicate if changes were made. The images or other third party material in this article are included in the article's Creative Commons licence, unless indicated otherwise in a credit line to the material. If material is not included in the article's Creative Commons licence and your intended use is not permitted by statutory regulation or exceeds the permitted use, you will need to obtain permission directly from the copyright holder. To view a copy of this licence, visit http://creativecommons.org/licenses/by/4.0/.
\end{abstract}

(C) The Author(s) 2021 